\title{
The SOCIMIs in Spain. An investment opportunity in the real estate sector
}

\section{Las SOCIMIs en España. Una oportunidad de inversión en el sector inmobiliario}

\author{
$\mathrm{M}^{\mathrm{a}}$ Celia López-Penabad ${ }^{1}$ \\ Adrián VÁzQuez PARCERO ${ }^{2}$ \\ University of Santiago de Compostela (Spain)
}

Recibido el 21 de julio de 2017, aceptado el 30 de enero de 2019

Publicado online el 17 de junio de 2019

$\mathrm{N}^{\mathrm{o}}$ de clasificación JEL: G23, C10

DOI: $10.5295 / \mathrm{cdg} .170803 \mathrm{cl}$

\begin{abstract}
:
The purpose of the present work is to analyze the SOCIMIs (Real estate listed investment trusts in Spain), its performance and its potential as a diversification asset between June 2014 and December 2017. The tax advantages they offer, the main incentive for the creation of these types of companies, are bringing about an increase in development of real estate investment in Spain, which is behind other developed markets where they are generally called REITs (Real Estate Investment Trusts). First, the characteristics, operation, evolution in the market, portfolios and shareholders' composition are studied. Next, the analysis shows high performance levels measured by the modified Sharpe Ratio and the Jensen's Alpha for the main SOCIMIs on the market as well as a high portfolio diversification potential demonstrated by the Markowitz Efficient Frontier Model. SOCIMIs are characterized by being less risky investments than the market in general. Compared to traditional Real estate listed companies on the continuous market, SOCIMIs show better performance and lower levels of risk and, in general, all the companies studied-SOCIMIs and traditional Real estate listed companies- can be defined as defensive investments, less risky than the market.
\end{abstract}

\section{Keywords:}

SOCIMIs, modified Sharpe Ratio, Jensen's alpha, performance, diversification.

\section{Resumen:}

El objetivo del presente trabajo es analizar las SOCIMIs, Sociedades Cotizadas de Inversión Inmobiliaria, su performance y su potencial como activo diversificador para el período desde junio de 2014 a diciembre de 2017. Las ventajas fiscales que ofrecen, principal incentivo a la hora de la creación de este tipo de sociedades, están permitiendo impulsar el desarrollo de la inversión colectiva inmobiliaria en España, no sin retraso con respecto a otros mercados desarrollados en donde en general son denominadas REITs (Real Estate Investment

1 Departamento Economía Financiera y Contabilidad. Facultad CC. Económicas y Empresariales. Avda. do Burgo, s/n ,15782 Santiago de Compostela, A Coruña (Spain). celia.lopez@usc.es

2 Master en Banca, Finanzas y Seguros (USC). Facultad CC. Económicas y Empresariales. Avda. do Burgo, s/n, 15782 Santiago de Compostela, A Coruña (Spain). adrivazquez@movistar.es 
Trusts). Una vez estudiadas sus características, funcionamiento, evolución en el mercado, composición de sus carteras y accionariado, el análisis pone de manifiesto niveles de performance elevados medidos mediante la Ratio de Sharpe modificada y el Alfa de Jensen para las principales SOCIMIs del mercado. Se caracterizan por ser inversiones menos arriesgadas que el mercado en general, con un elevado potencial diversificador del riesgo en carteras, demostrado mediante el estudio de Fronteras eficientes propuesto por Markowitz, en comparación con empresas Inmobiliarias tradicionales cotizadas en el mercado continuo. Respecto a estas últimas, presentan mejor performance y menores niveles de riesgo, aunque en general todas las empresas estudiadas se pueden encuadrar en inversiones defensivas, menos arriesgadas que el mercado.

\section{Palabras clave:}

SOCIMIs, Ratio de Sharpe modificado, Alfa de Jensen, performance, diversificación. 


\section{INTRODUCTION}

The Great Recesion which was experienced by the world's economies from 2008 onwards, known as the "developed countries' crisis" lead to a profound financial crisis which ended up as a debt crisis, evolving differently in each economy. In Spain, the increase in unemployment stood out and the construction sector was one of the most badly affected due to the real estate bubble. As a result, both the real estate sector as well as construction were considerably weakened and society blamed them for the recession experienced, creating a certain mistrust towards them.

In Spain, up until now, the main body of collective real estate investment was the Real Estate Investment Funds (Fondos de Inversión Inmobiliaria, FII). These funds, managed by the great Spanish financial entities, were surrounded by the grave real estate crisis, which, along with the difficult situation which has characterized this kind of collective investment from its beginnings (the end of 1994) led to the suspension of payments and even their dissolution, leaving only three funds at the moment, still in dissolution (Maside-Sanfiz et al. 2016). The Real Estate Investment Societies (Sociedades de Inversión Inmobiliaria, SII) are scarce in the market, at present there being only 4 entities registered on the CNMV, one of them in liquidation (Comisión Nacional del Mercado de Valores, CNMV).

In 2009, the Spanish government regulated a new investment vehicle called SOCIMI (Sociedades Anónimas Cotizadas de Inversión Inmobiliaria) following the example of the REITS (Real Estate Investment Trust) which are quite sucessful in other economies.

The SOCIMIs, like the REITs, are quoted investment companies, more transparent than the FII, and enjoy a special tax regime which offers investors the chance to acquire real estate assets, maintaining a professionalized management. It was the need to boost the real estate market which facilitated the creation of the SOCIMIs, which, from 2014 have been enjoying intense development in the market.

Recently, the real estate market in general, and especially the real estate company sector, have become of great interest to the investors. This is due to the low profitability of other types of assets, the reasonable risk profile of the underlying business and the recent recovery of Spain's economy.

Profitability and liquidity are basic aspects to be taken into account for any kind of investment as well as real estate investment, which, along with their potencial as a diversifiying asset makes SOCIMIs important assets when constituting portfolios.

The aim of the paper is to analyze the SOCIMIs sector in Spain, the performance of these entities compared to traditional investment in quoted Real estate companies and their possibilities as a diversifying asset in porfolios. For this reason, this study was organized as follows, in the second section, the antecedents are developed which gave rise to the SOCIMIs in Spain, legal aspects and taxation, to be inmediately followed by looking at the sector as a whole, analyzing aspects such as capitalization, the launch onto the market, shareholders and investment value. In the next section, the sample used and the methodology followed are described. The results obtained regarding performance and diversification are explained in the last section, ending with the conclusions. 


\section{SOCIMIs IN SPAIN}

\subsection{Antecedents and regulation}

The SOCIMIs arose from the so-called REITs, a real estate investment vehicle extended worldwide. The REITs were created in the US during 60's, later experiencing a time of some growth, until the boom of the 90's when they were adopted by many other countries such as Australia and the UK.

The SOCIMIs began to be regulated with the passing of Law $11 / 2009$ on $26^{\text {th }}$ October $2009^{3}$, which established the main aim as boosting the urban market as well as stating special taxation for this type of societies. With this law, the goverment endeavoured to reactivate the real estate market in Spain by channeling investment into it, as well as helping citizens to access real estate investment.

The Law defines the SOCIMIs as listed limited companies for real estate investment whose main activity is to acquire, promote and restore urban assets for renting, either directly or through shares in other SOCIMIs' capital. The SOCIMIs belong to the equity REITs category as they can only invest in pure real estate assets (Table 1).

Table 1

\section{REITs categories}

\begin{tabular}{|l|l|}
\hline Equity REITs & $\begin{array}{l}\text { Main investment is in real estate to obtain rent by their renting. These profits } \\
\text { are divided among the shareholders as dividends. Worldwide they are the most } \\
\text { common REITs. }\end{array}$ \\
\hline Mortgage REITs & $\begin{array}{l}\text { Focused on acquiring mortgage portfolios, as well as securitization. Income } \\
\text { derives from periodical interest payments by the borrowers. }\end{array}$ \\
\hline Hybrid REITs & $\begin{array}{l}\text { Share characteristics from both previous groups by investing in both real } \\
\text { estate and mortgage loans or mortgage-backed securities. }\end{array}$ \\
\hline
\end{tabular}

Source: Authors.

No SOCIMI was created in the following four years in the market which lead to a revision of the said Law at the end of 2012. Law 16/2012, $27^{\text {th }}$ December $^{4}$ permitted the SOCIMIs greater flexibility in likeness to the REITs.

The main modifications focused on their taxation, making the SOCIMIs tax free (Corporate Tax at $0 \%$ ) and their shareholders passive subjects.

Another fundamental aspect in the changes was the SOCIMIs' obligation to pay out at least $80 \%$ of the profits for rents, as well as having a minimum of $80 \%$ of their asset value invested in urban real estate for rent.

The minimum social capital was also reduced, from 15 million down to 5 million euros, permitting investment in only one property and completely eliminating debt limits.

The requisites of the new Law are summarized in Table 2.

3 BOE n $^{\circ} 259$ Tuesday 27th October 2009.

4 BOE no 312 28th December 2012. 
Table 2

\section{SOCIMIs legal requirements}

\begin{tabular}{|c|c|}
\hline Minimal Social Capital & 5.000.000 Euros \\
\hline Asset composition & $\begin{array}{l}\text { At least } 80 \% \text { in real estate for rent, on land to promote property } \\
\text { with these characteristics (to start within } 3 \text { years) and in shares in } \\
\text { the capital or equity of other SOCIMIs. }\end{array}$ \\
\hline Number of property rented & At least 8 properties \\
\hline Length of renting contract & At least 3 years \\
\hline Composition of the incomes & $\begin{array}{l}\text { At least } 80 \% \text { should come from renting properties or dividends or } \\
\text { shares in profits from shares in other entities. }\end{array}$ \\
\hline Result distribution & $\begin{array}{l}\text { - Total benefits from dividends or shares from other SOCIMIs. } \\
\text { - At least } 50 \% \text { of the profits from the transfer of property and } \\
\text { shares from other SOCIMIs. } \\
\text { - At least } 80 \% \text { of the remaining profit. }\end{array}$ \\
\hline $\begin{array}{l}\text { Special tax regime in corpo- } \\
\text { ration tax }\end{array}$ & $\begin{array}{l}\text { - Type of tax (if it complies with the requisites): } 0 \% \text { from profit } \\
\text { from property rent. } \\
\text { - Type of tax (if it does not fulfil requisites): } 30 \% \text { of profits ob- } \\
\text { tained from property rent. } \\
\text { - Type of tax: } 19 \% \text { on the part of the tax base corresponding to } \\
\text { dividends or profit sharing distributed to the partners. }\end{array}$ \\
\hline Other taxes & $\begin{array}{l}\text { - Exemption of corporate transactions in constitution, capital in- } \\
\text { crease and non-monetary contributions. } \\
\text { - } 95 \% \text { tax relief on the acquisition of housing for rent and land for } \\
\text { promotion (ITPYAJD). }\end{array}$ \\
\hline
\end{tabular}

Source: Adapted from Fernández and Romero (2016, p. 62).

The new regulation, like the previous one, obliges SOCIMIs to join in any multilateral trading system. This latest Law allows listing on alternative markets, the most usual being the Mercado Alternativo Bursátil (MAB) in the Spanish case.

Regarding minimum requirements for distribution, the SOCIMIs can count on more advantageous ones than the REITs ${ }^{5}$, as they do not need to include a minimum number of shareholders. However they demand that $25 \%$ of the capital (or an estimated market value of 2 million euros) should be in the hands of shareholders with less than 5\%. Similarly, their taxation is more advantageous than for other similar investment vehicles such as FII, SII, Limited Companies and Renting Entities.

5 The REITs should have, from the second year on, a mínimum of 100 shareholders and $50 \%$ of its capital cannot belong to five or fewer people for half the tax year. 
It is important to establish that these entities have two years of transition to fulfil the criteria which this type of vehicle demands, the SOCIMIs being able to be set up in the same way.

\subsection{The SOCIMIs sector in Spain}

At the end of 2013, the MAB opened up an area of negociation for the SOCIMIs with two inclusions, Entrecampos Cuatro and Promorent. The next addition, Mercal Inmuebles, ocurried about half way throught 2014. In later years, the number of SOCIMIs increased, 8 in 2015 and in 2016 the number reached 30, with 52 in 2017. As of April 2018, there were 56 entities of this type on the Spanish stock exchange (BME 2015, 2016, 2017; BME web).

On the Spanish continuous market there are four SOCIMIs listed. Lar and Hispania joined about the same time, March 2014, and Merlin and Axiare in June of the same year. With effect from $1^{\text {st }}$ January 2017, Inmobiliaria Colonial became a SOCIMI, listed on the continuous market and became the second SOCIMI in the Ibex-35, after Merlin. At the end of 2017, Inmobiliaria Colonial launched a takeover bid for all the Axiare shares and the latter disappeared from the market.

The huge increase and good perspectives in the SOCIMIs sector lead to the creation of a new sector index in the Financial Services and Real Estate Sector in January 2015. The SOCIMIs index groups the Real estate investment companies on the Madrid continuous market. On December $31^{\text {st }} 2014$ the index calculation was based on 1.000 points.

Recently, the continuous market SOCIMIs have been concentrating on capturing assets which make their projects feasible. Foreign interest is essential to achieving their goals; at the beginnig of December 2016 the declared significant holdings belonging to foreign investors in these societies was 10\% for Merlin, 45\% Axiare, 58\% Lar and 73\% Hispania. A year later, December 2017, foreign investor' holdings varied, from 7\% Merlin, 14\% Axiare, 59\% Lar, 75\% Hispania and 23\% Colonial.

Figure 1 shows the evolution of the prices for entities on the continuous market. The SOCIMIs' sector shows a slight upward movement on the market until 2016, some entities, such as Lar and even Merlin show a lateral tendency. During 2017, a stable upward tendency has intensified with Axiare, Hispania and Colonial (Figure 1). Real trading volume has gone from 3.345 million euros in 2014, to nearly 7.350 millon euros in 2016 and to more than 10.000 millon euros in December 2017.

When talking about listed companies, a basic aspect is their market capitalization (Table A1 in Annex). A great increase has been seen in SOCIMIs on the continuous market, going from 8.246 millon euros in 2015, to 9.527 euros in 2016 and finally 12.907 in 2017. This demostrates the intensity with which these entities are joining the markets, which, in spite of not being around for long, are becoming prominent when any investor's portfolio is being formed.

Analyzing the importance of the great entities on the continuous market, in terms of market capitalization and absolute values, supposes around 13.000 million euros as opposed to the 20.000 million of the SOCIMIs in total. It is true that their relative importance has declined somewhat (62\% in $2017,70 \%$ in 2015) but in absolute terms, the capitalization of the big SOCIMIs has increased considerably, although very far from the increase of the rest. This is basically due to the large number of incorporations in these last three 
years. The two biggest SOCIMIs on the market, Merlin and Colonial, which belong to the Ibex 35, supposed $42 \%$ of the total capitalization of all the SOCIMIs at the end of 2017 (Table A1 Annex).

Figure 1

\section{Trends of SOCIMIs's stock prices}

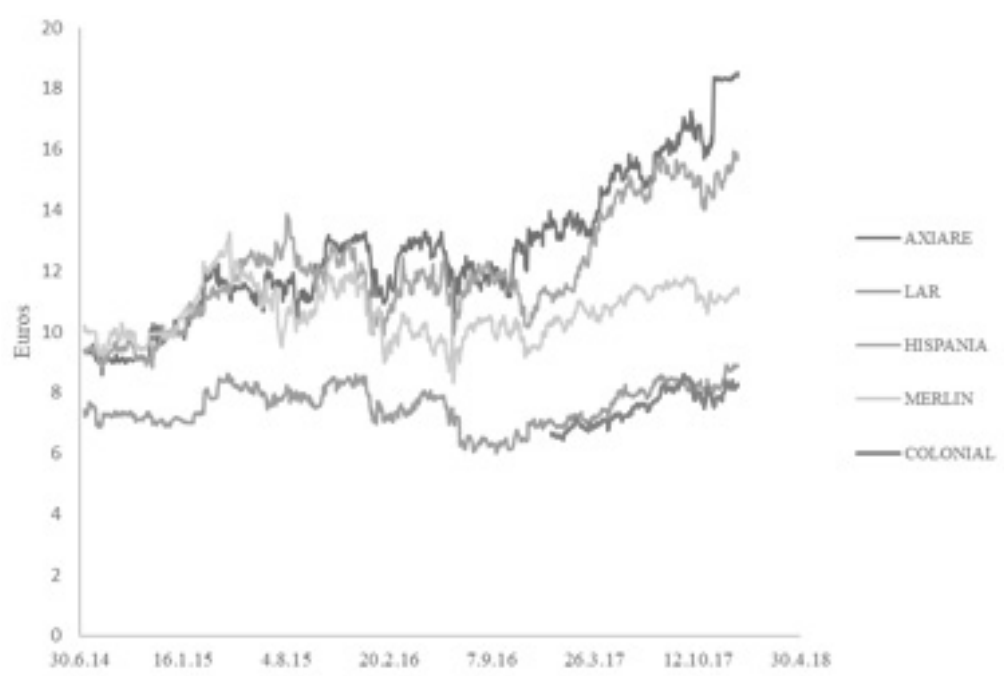

Source: Authors, data from Infobolsa.

In Figure 2, the percentage of real estate investments is shown at the end of the financial year for the large SOCIMIs regarding the total investment of all those registered on the markets ${ }^{6}$. As may be seen, between 2014 and 2015, there was a concentration of real estate investment for the four big SOCIMIs. The investments of Lar España stand out (it goes from having less than $1 \%$ of total investment to $5 \%$ in 2015) as does Merlin, which goes from $7 \%$ in 2014 to $21 \%$ in 2015 . These increases are at the cost of the relative diminishing of the rest of the SOCIMIs which, at present, are listed on the Spanish markets, which go from $54 \%$ of the total asset value to $40 \%$ in 2015. In 2016, Merlin's growth stands out as it possesses $36 \%$ of real estate investment of the total Spanish SOCIMIs. During 2017, the percentage of real estate investments continues to decrease for the rest of the SOCIMIs.

Despite the weight of the rest of SOCIMIs diminishing in 2016, their real estate investment increased by $15 \%$, which was much lower than $125 \%$ obtained from the four main companies on the continuous market.

The value of total real estate investment of this type of societies closed 2015 to the value of 13,040 millones euros as opposed to the 20,521 millon euros which were registered

6 Colonial was included in these entities for its size and because in December 2017 it became a SOCIMI as of 1st January. Axiare was included because in spite of its disappearing after Colonial's takeover of it, it was active from 2014 to December 2017, when it was merged. 
in 2016, that is $73 \%$ more. In 2017, all the SOCIMIs together invested 20,300 millon euros, and the distribution among the most important entities is similar to that of 2016.

Figure 2

\section{Percentage of real estate investment in the hands of the large SOCIMIs out of the total real estate investment of the group of SOCIMIs, 2014-2017}
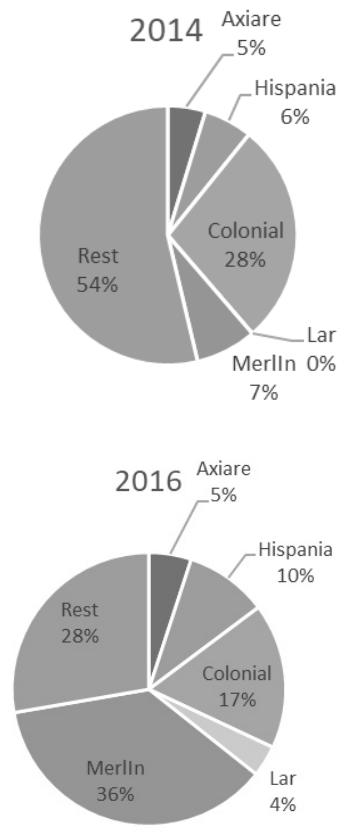
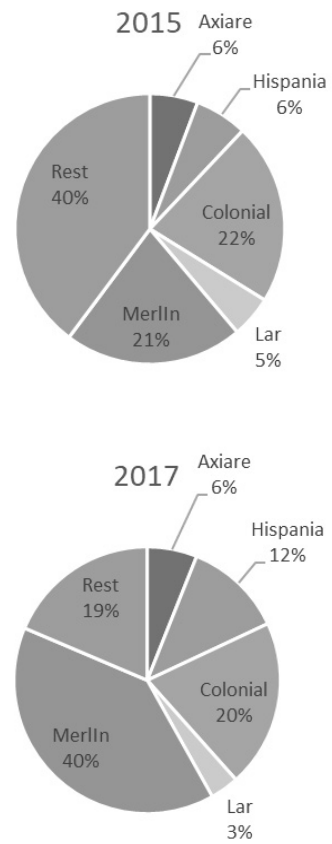

Source: Authors' own, data Sabi.

As regards the make-up of the SOCIMIs portfolios, in Figure 3, housing, officies, shopping malls and business premises are the most usual types of real estate in the societies studied.

Concentrating on the societies on the continuous market, these are their portfolio assets at the end of 2017:

- Axiare: its portfolio mainly comprises of high level office buildings (70\%), also including logistic and commercial areas (30\%), mainly in Madrid and Barcelona.

- Hispania: in 2017 it became the top hotel owner in Spain (46 hotels with more than 13.100 rooms), it also has office and residential areas situated mainly in Madrid and Barcelona $^{7}$. At market price, for area of business, its GAV (Gross Asset Value) was: Hotels $66 \%$, Office Blocks $24 \%$ and residential areas $10 \%$.

7 In July 2018, Blackston acquired Hispania, which made this fund the largest hotel owner in Spain. One of the aims of the fund was to exclude Hispania from the Stock Exchange. 
- Lar: it has almost thirty assets of which 19\% are malls, 3 office blocks, 6 logistic complexes and 14.075 housing units. Its presence stands out in the Spanish capital, as well as México and Perú.

- Merlin: the largest SOCIMI on the market specializes in the most stable business in real estate, renting. Its portfolio comprises offices (37\%), shopping malls (14\%), business premises $(32 \%)$ and hotels $(7,5 \%)$. Business premises are mainly featured, it possesses 990 , followed by 139 offices and 18 malls as well as 41 logistic warehouses. As regards its presence, its assets are to be found thoughout the península, including Portugal. Although almost $11 \%$ of its total assets are to be found in Catalonia.

Figure 3

\section{Porcentage of SOCIMIs which own each asset in their portfolio 2017}

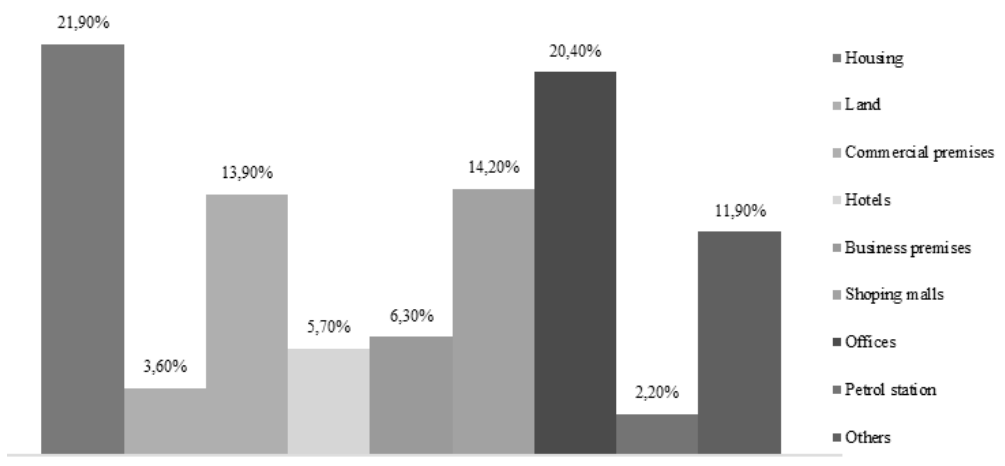

Source: Authors' own, data company websites.

Talking about entities in the real estate sector, it is necessary to refer to the Net Asset Value (NAV) as a way to assess a Real estate company. It deals with voluntary accounting information which companies are not required to divulge and represents the market value of the company's assets minus the total value of the liabilities, which helps determine the net book value which corresponds to each of the societies shares (Roig Hernando and Soriano Llobera 2015).

In regard to this aspect, it is worth highlighting that the larger companies quoted below (discounted) the NAV, except for Axiare ${ }^{8}$ (Table 3). This situation demonstrates that, in spite of the increase in housing prices, the share price continues below the book asset value, a characteristic which might make Spanish SOCIMIs attractive for any investor.

8 It must be remembered the price of Axiare, at the end of 2017, was moving strongly upwards due to the takeover bid by Colonial. 
Table 3

SOCIMIs' NAV and quotes

\begin{tabular}{|l|l|l|l|l|l|}
\hline & & $31 / 12 / 2014$ & $31 / 12 / 2015$ & $31 / 12 / 2016$ & $31 / 12 / 2017$ \\
\hline Axiare & NAV by share & & 11,60 & 13,60 & \\
\hline Lar & Quote & 10,38 & 13,20 & 13,82 & 18,42 \\
\hline & NAV by share & & & 9,20 & 10,27 \\
\hline Hispania & Quote & 7,17 & 8,28 & 7,03 & 8,89 \\
\hline & NAV by share & & 11,80 & 13,72 & 15,93 \\
\hline Merlin & Quote & 10,01 & 12,10 & 11,19 & 15,70 \\
\hline & NAV by share & 10,49 & 9,85 & 11,23 & 13,25 \\
\hline Colonial & Quote & 7,84 & 11,39 & 10,33 & 11,30 \\
\hline & NAV by share & & & & 8,60 \\
\hline & Quote & & & & 8,28 \\
\hline
\end{tabular}

Source: Author's own, data Company webs and Infobolsa.

As regards the shareholding of the entities on the continuous market (see Figure 4), the free float which they all possess, except Lar, which excedes $50 \%$ of its social capital can be highlighted. Lar's capital is very widespread, the Pimco fund accounts for $19 \%$ of the shares, followed by Grupo Lar (only 10\%) and other funds such as Franklin Templeton, BlackRock and Columbia Threadneedle. Therefore, they are companies with relatively disperse shareholding. The $22 \%$ of the Banco Santander of Merlin's capital is outstanding. Similarly, several investment funds, the majority international, have portfolios with significant parts of the SOCIMIs. This is the case for the US giant BlackRock which is present in the capital of them all.

In spite of the surge which the creation of new societies in the SOCIMI group are enjoying, one out of five is listed at the same initial price. This is evidenced mainly in the MAB and, in many cases, is down to the lack of investor confidence in this type of alternative market. Also the need to be listed to be constituted as a SOCIMI and so obtain the corresponding taxation advantages, obliges many of them to count on limited minority shareholders and, as a result, hardly any movement on the market. Of the 47 SOCIMIs, the MAB closed with in 2017, 11 showed no movement at all throughout the year and another 19 had a trading volume of less than $1 \%$ of their capitalization; 10 had $5 \%$ above. Altogether, 67.3 million euros traded for 7,912.9 million euros of capitalization, i. e. $0,85 \%$. The ones which trade the most are the companies which are listed on the continuous market and Entrecampos Cuatro on the MAB (the first SOCIMI to be listed) (BME 2017).

In 2017, in terms of dividends, 27 SOCIMIs shared out 423,35 million euros, $56 \%$ of the total amount shared out from 2013 to 2016 . Besides, this figure represents $1.61 \%$ of the total dividends paid by all those listed on the Spanish stock exchange during the exercise (BME 2017). 
Figure 4

\section{Composition shareholding December 2017, SOCIMIs on the continuous market}
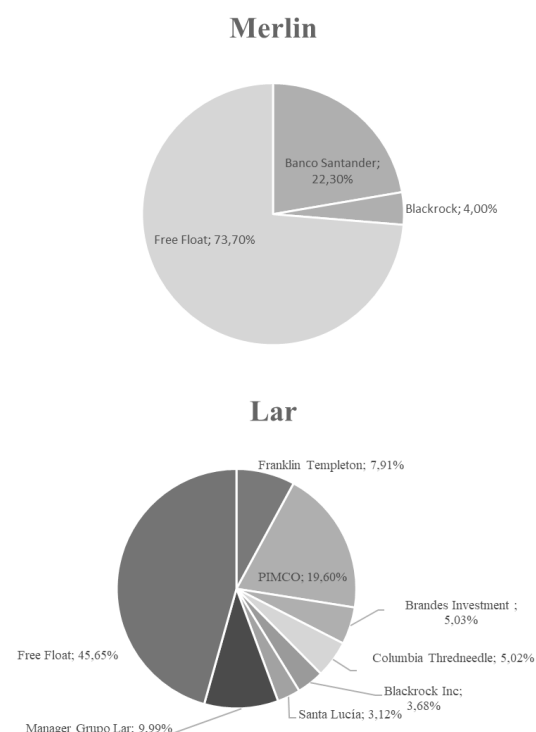

Colonial

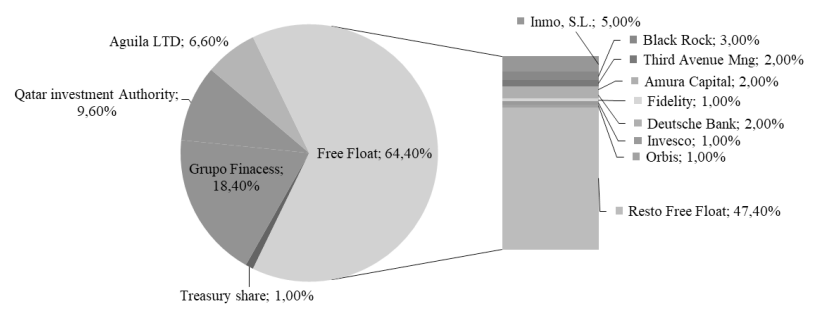

Source: Authors' own, data company websites.

\section{PROPOSED METHODOLOGY}

The main aim of the paper is to study SOCIMIs performance as well as their diversifier portfolio potencial. To extend the analysis, the SOCIMIs' results will be compared to those obtained by Real estate businesses (Limited Companies) which are, at present, included in the Real estate sector on the continuous market.

\subsection{Sample selection and data}

In order to carry out this research it was necessary to find the closing prices of the listed shares and indeces. The period under study is from June 2014 to December 2017. 
Regarding the SOCIMIs, the four companies which were listed on the continuous market were considered, Axiare Patrimonio SOCIMI, S.A.; Lar España Real Estate SOCIMI, S.A.; Hispania, S.A. and Merlin Properties, S.A. The companies listed on the MAB do not have sufficient liquidity ${ }^{9}$.

When selecting the entities which would make up our sample of Real estate companies, they were chosen according to importance and data availability: Colonial, Inmobiliaria del Sur, Montebalito, Realia and Renta Corporación. In Tables A1 and A2 in the Annex, all the SOCIMIs and Real estate companies appear, along with their ISIN code, their listed market, their market capitalization and the weight of each in the sector.

To represent the market, the following indeces were used:

1. Ibex 35, Spanish continuous market index.

2. The continuous market real estate index belonging to the group of the General Index of the Madrid Stock Exchange (IGBM Inmo).

As a risk-free asset the one year Spanish Treasury bond was used. The data were obtained from the Infobolsa web page, as well as from Yahoo Finance, the Banco de España and the Sabi Database, all of them monthly. In Table A3 of the Annex, the descriptive statistics of the series used are summarized.

\subsection{Methodology}

Methodology is developed in two stages. Firstly, the risk adjusted performance is studied. Performance is the return of a financial investment and the level of risk it bears. As indicators of performance, the Sharpe ratio (SR) and the Jensen's alpha will be used, and they will be completed with dividend yield ratios, Return on Assets (ROA), Return on Equities (ROE), solvency and leverage ratios. Secondly, the Markowitz Mean-Variance Model will be used to determine efficient frontiers (Markowitz 1952).

The SR measures the excess return (or risk premium) per unit of deviation in an investment asset or portfolio.

$$
\mathrm{SR}_{\mathrm{p}}=\frac{\overline{\mathrm{R}_{\mathrm{p}}}-\overline{\mathrm{R}_{\mathrm{f}}}}{\sigma_{\mathrm{p}}}
$$

The numerator is the expected value of the excess of the asset return over the risk-free asset and the denominatior is the variability of the asset return.

Breakdown of SR:

$$
\begin{aligned}
& \bar{R}_{p}=\text { Monthly expected return of the asset } \mathrm{p} . \\
& \bar{R}_{f}=\text { Monthly expected return of the risk-free asset. } \\
& \sigma_{p}=\text { Standard deviation of the asset excess return. }
\end{aligned}
$$

9 Colonial has not been inserted as a SOCIMI because in December 2017 it had just reconverted to SOCIMI. On the contrary, Axiare was included because it disappeared in December 2017, but had data for all the period studied. 
The SR characterizes how well the return of an asset compensates the investor for the risk taken. The greater the ratio, the more interesting the portfolio for the investor. However, if the excess of the asset return is negative, the SR may cause a wrong sorting, for example, two investments which reach the same excess of return negative but with different standard deviations, in this case the SR would indicate that the portfolio with the greater standard deviation is the best, in spite of reaching the same negative return with greater risk. Several authors propose alternative indeces to get the adequate sorting of the investments with negative excess returns (Israelsen 2003, 2005; Ferruz and Sarto 2004). As indicated by Israelsen $(2003,2005)$, the modified SR (mSR) which is described as follows is applied.

$$
m S R=\left\{\begin{array}{c}
\frac{\bar{R}_{p}-\bar{R}_{f}}{\sigma_{p}}, \text { if } \bar{R}_{p} \geq \bar{R}_{f} \\
\frac{\bar{R}_{p}-\bar{R}_{f}}{\sigma_{p}\left(\left(\bar{R}_{p}-\bar{R}_{f}\right) / a b s\left(\bar{R}_{p}-\bar{R}_{f}\right)\right)}, \text { if } \bar{R}_{p}<\bar{R}_{f}
\end{array}\right.
$$

As a second tool to assess the performance of the assets studied, the Jensen's alpha is employed. This indicator analyzes the good/bad management of a portfolio, as it facilitates the comparison between obtained return and the theoretic amount which, according to the Capital Asset Pricing Model (CAPM), it corresponds to. The CAPM formula determines the fair value of a stock according to the stock's beta and the market risk premium.

Thus, Jensen's alpha provides information about the excess (or lack) of return which the manager is able to obtain (to beat or not the market) over the theoretical expected return. The beta coefficient is a measure of the portfolio systematic risk of the SOCIMI in our case, and, ultimately, also of the strategy followed.

The model to be estimated is the following:

$$
\mathrm{R}_{\mathrm{it}}-\mathrm{R}_{\mathrm{ft}}=\alpha+\beta_{1}\left(\mathrm{R}_{\mathrm{Mt}}-\mathrm{R}_{\mathrm{ft}}\right)+\varepsilon_{\mathrm{it}}
$$

$R_{M t}=$ Monthly expected return on Ibex 35 or IGBM Index in $\mathrm{t}$.

$R_{f t}=$ Monthly expected return of the risk free asset in period $\mathrm{t}$ (one year Spanish Treasury bond)

$R_{i t}=$ Monthly espected return of asset $\mathrm{i}$ in period $\mathrm{t}$.

$\varepsilon_{\mathrm{it}}=$ Random error for asset $\mathrm{i}$ in period $\mathrm{t}$.

Thus, a positive alpha implies that the portfolio studied obtains a higher return than one which replicates the market's, thus following a passive strategy. A negative alpha implies a lower return to that estimated by the CAPM, that which corresponds to the level of assumed risk.

Therefore, by means of the two previously exposed indicators, a detailed comparison of the varying SOCIMIs and Real estate companies can be assessed and carry out.

Regarding the analysis of the risk diversification, the portfolio management proposed by Markowitz (1952) will be followed, it represents efficient frontiers and assessments of the potential of risk diversification. 
As input for the model expected returns, standard deviations and covariances between the pairs of assets are required. The approach is as follows:

$$
\text { Minimize } \sigma_{p}=\left[\sum_{i=1}^{N} x_{i}^{2} \sigma_{i}^{2}+\sum_{i=1}^{N} \sum_{j=1}^{N} 1_{i \neq j} x_{i} x_{j} \sigma_{i j}\right]^{1 / 2}
$$

$$
\text { Subject to: (1) } \sum_{\mathrm{i}=1}^{\mathrm{N}} \mathrm{x}_{\mathrm{i}}=1
$$

(2) $\sum_{i=1}^{N} x_{i} \bar{R}_{1}=\overline{R_{p}}$

Being:

$$
\begin{aligned}
& \sigma_{\mathrm{p}}=\text { Standard deviation of the return of the portfolio } \mathrm{p} . \\
& \mathrm{x}_{\mathrm{i}}=\text { Proportion which portfolio } \mathrm{p} \text { invests in asset } \mathrm{i} \text {. } \\
& \sigma_{\mathrm{i}}^{2}=\text { Variance of asset } \mathrm{i} \text {. } \\
& \sigma_{\mathrm{ij}}=\text { Covariance between assets } \mathrm{i} \text { and } \mathrm{j} . \\
& \overline{\mathrm{R}_{\mathrm{l}}}=\text { Expected return of asset } \mathrm{i} \text {. } \\
& \overline{\mathrm{R}_{\mathrm{p}}}=\text { Expected return of the portfolio. }
\end{aligned}
$$

The approach consists of minimizing the risk of all the possible combinations of assets at each level of given return allowing short sales. The software used was Excel (Microsoft Office 2016) and the complements of Solver and Solver Table were availed to minimize the previous approach and repeat it. Then the efficient portfolios obtained are represented to analyze the diversifying power of each SOCIMI, and ultimately, their portfolios.

\section{RESULTS}

Following, outcomes are discussed. Firstly, the results of the performance analysis using mSR and Jensen's alpha. The information about dividend yields, ROA and ROE, and solvency and leverage ratios has been included. Secondly, the diversifying effect using Markowitz' Mean-Variance Model will be analyzed.

\subsection{Measurement of SOCIMIs and Real estate performance}

In Table 4 and Figure 5, the mSR, ROA, ROE, solvency ratio, leverage and dividend yield can be seen for the SOCIMIs and Real estate companies. The mSR was increased for the years studied (2014 to 2017) as much for the reduction in return of the one year Spanish Treasury bond as for the increase in returns. In some periods, for some companies, the spread was negative, and in those cases, instead of dividing by the standard deviation, it was multiplied, as indicated in equation (2). Table 4 contains the value of the $\mathrm{mSR}$ for each year and entity. The year 2017 was extraordinarily good for the SOCIMIs, they all saw improvements in their mSR. Colonial, which appears in Figure 5 in the Real estate group, in 2017, after becoming a SOCIMI also saw its mSR increase noticeably. 
Figure 5

Modified Sharpe Ratio evolution SOCIMIs and Real estate companies

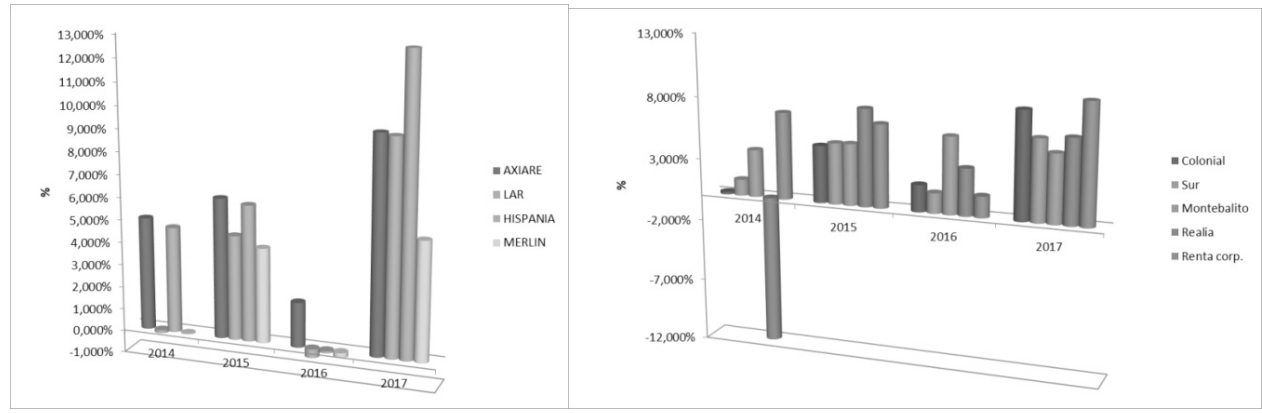

Source: Authors, data from Infobosa.

In Table 4, it may be observed that dividend yield is much greater for the SOCIMIs than for the Real estate companies, which in many cases do not share dividends. ROA and ROE of the SOCIMIs have undergone a constant improvement and their solvency and leverage ratios reflect a good situation, which, moreover, is fairly similar for all the entities. Real estate company ratios generally show a worse financial-economic situation, with less profitability, solvency and greater leverage, although with greater diversity than for the SOCIMIs group.

Table 4

Modified Sharpe Ratio, ROA, ROE, solvency, leverage and dividend yield for SOCIMIs and Real estate companies

\begin{tabular}{|l|l|c|c|c|c|}
\hline & & 2014 & 2015 & 2016 & 2017 \\
\hline Axiare & mRS (montly) & $5,03 \%$ & $6,21 \%$ & $1,99 \%$ & $9,55 \%$ \\
& ROA & $4,27 \%$ & $7,54 \%$ & $9,48 \%$ & $11,31 \%$ \\
& ROE & $5,26 \%$ & $10,32 \%$ & $15,02 \%$ & $17,68 \%$ \\
& Solvency Ratio & 0,22 & 11,19 & 9,92 & 3,62 \\
& Leverage & $20,19 \%$ & $34,95 \%$ & $57,05 \%$ & $55,18 \%$ \\
& Lar & $0,39 \%$ & & $1,16 \%$ & $0,76 \%$ \\
& Dividend yield & $-0,13 \%$ & $4,63 \%$ & $-0,38 \%$ & $9,45 \%$ \\
& mRS (monthly) & $0,79 \%$ & $4,77 \%$ & $6,96 \%$ & $8,72 \%$ \\
& ROA & $0,89 \%$ & $7,63 \%$ & $11,26 \%$ & $14,77 \%$ \\
& ROE & 11,79 & 3,54 & 2,85 & 2,1 \\
& Solvency Ratio & $11,03 \%$ & $57,75 \%$ & $58,30 \%$ & $58,50 \%$ \\
& Leverage & & $0,91 \%$ & $0,54 \%$ & $5,06 \%$ \\
\cline { 2 - 6 } & Dividend yield & & & &
\end{tabular}


The SOCIMIs in Spain. An investment opportunity in the real estate sector

\begin{tabular}{|c|c|c|c|c|c|}
\hline \multirow[t]{6}{*}{ Hispania } & mRS (montly) & $4,72 \%$ & $6,03 \%$ & $-0,09 \%$ & $13,01 \%$ \\
\hline & ROA & 2,7 & $4,89 \%$ & $15,34 \%$ & $9,61 \%$ \\
\hline & ROE & 3,13 & $8,26 \%$ & $23,42 \%$ & $15,42 \%$ \\
\hline & Solvency Ratio & 15,52 & 3,51 & 3,76 & 1,10 \\
\hline & Leverage & 14,56 & $64,12 \%$ & $49,13 \%$ & $51,27 \%$ \\
\hline & Dividend yield & & & $2,81 \%$ & $2,63 \%$ \\
\hline \multirow[t]{6}{*}{ Merlin } & mRS (monthly) & $-0,04 \%$ & $4,21 \%$ & $-0,22 \%$ & $5,25 \%$ \\
\hline & ROA & $2,10 \%$ & $0,83 \%$ & $5,43 \%$ & $9,28 \%$ \\
\hline & ROE & $3,88 \%$ & $1,96 \%$ & $12,24 \%$ & $19,45 \%$ \\
\hline & Solvency Ratio & 4,51 & 0,4 & 4,03 & 2,24 \\
\hline & Leverage & $82,05 \%$ & $118,38 \%$ & $122,00 \%$ & $107,47 \%$ \\
\hline & Dividend yield & & $1,61 \%$ & $3,93 \%$ & $4,08 \%$ \\
\hline \multirow[t]{6}{*}{ Colonial } & mRS (monthly) & $0,20 \%$ & $4,56 \%$ & $2,14 \%$ & $8,50 \%$ \\
\hline & ROA & $2,10 \%$ & $0,83 \%$ & $5,43 \%$ & $9,28 \%$ \\
\hline & ROE & $3,88 \%$ & $1,96 \%$ & $12,24 \%$ & $19,45 \%$ \\
\hline & Solvency Ratio & 4,51 & 0,40 & 4,03 & 2,24 \\
\hline & Leverage & $82,05 \%$ & $118,38 \%$ & $122,00 \%$ & $107,47 \%$ \\
\hline & Dividend yield & & $1,61 \%$ & $3,93 \%$ & $4,08 \%$ \\
\hline \multirow[t]{6}{*}{ Sur } & mRS (monthly) & $1,30 \%$ & $4,86 \%$ & $1,61 \%$ & $6,45 \%$ \\
\hline & ROA & $2,31 \%$ & $2,20 \%$ & $1,53 \%$ & $1,64 \%$ \\
\hline & ROE & $9,32 \%$ & $8,78 \%$ & $6,45 \%$ & $6,17 \%$ \\
\hline & Solvency Ratio & 1,47 & 1,44 & 1,31 & 1,29 \\
\hline & Leverage & $273,85 \%$ & $258,12 \%$ & $261,29 \%$ & $220,03 \%$ \\
\hline & Dividend yield & $1,36 \%$ & $1,42 \%$ & $1,14 \%$ & $0,88 \%$ \\
\hline \multirow[t]{6}{*}{ Montebalito } & mRS (montly) & $3,80 \%$ & $4,90 \%$ & $6,08 \%$ & $5,42 \%$ \\
\hline & ROA & $7,96 \%$ & $-1,15 \%$ & $3,71 \%$ & $0,72 \%$ \\
\hline & ROE & $13,61 \%$ & $-1,49 \%$ & $4,56 \%$ & $0,94 \%$ \\
\hline & Solvency Ratio & 1,88 & 6,09 & 9,66 & 5,34 \\
\hline & Leverage & $33,44 \%$ & $21,29 \%$ & $19,34 \%$ & $24,54 \%$ \\
\hline & Dividend yield & & & & \\
\hline \multirow[t]{4}{*}{ Realia } & mRS (monthly) & $-11,84 \%$ & $7,74 \%$ & $3,73 \%$ & $6,68 \%$ \\
\hline & ROA & $-0,67 \%$ & $1,74 \%$ & $7,08 \%$ & $2,72 \%$ \\
\hline & ROE & $-4,77 \%$ & $5,26 \%$ & $14,45 \%$ & $5,24 \%$ \\
\hline & Solvency Ratio & 3,10 & 1,21 & 0,70 & 2,09 \\
\hline
\end{tabular}




\begin{tabular}{|l|lrrrr|} 
& Leverage & $528,23 \%$ & $138,03 \%$ & $92,42 \%$ & $89,81 \%$ \\
& Dividend yield & & & & \\
\hline $\begin{array}{l}\text { Renta Cor- } \\
\text { poración }\end{array}$ & mRS (monthly) & $6,96 \%$ & $6,63 \%$ & $1,68 \%$ & $9,47 \%$ \\
& ROA & $98,05 \%$ & $-8,72 \%$ & $4,65 \%$ & $10,63 \%$ \\
& ROE & $251,20 \%$ & $-20,24 \%$ & $9,82 \%$ & $21,59 \%$ \\
& Solvency Ratio & 3,21 & 3,10 & 4,01 & 2,56 \\
& Leverage & $125,30 \%$ & $113,45 \%$ & $97,90 \%$ & $79,44 \%$ \\
\hline
\end{tabular}

Source: Authors, data from Infobolsa and SABI.

It was necessary to estimate the parameters of the equation (3) to determine the Jensen's alpha for each SOCIMI and Real estate company. This was done for each index representing the market, in other words the estimations for each entity and the Ibex 35, and for the IGBM Inmo were carried out. Table 5 contains the main results of the estimations achieved.

As regards Ibex 35, Hispania, Colonial and Montebalito present significant positive alphas, which indicates the share obtained a higher return than the passive portfolio which would replicate the Ibex 35 . These are values with alphas close to $0.1 \%$ monthly, a remarkable profitability premium. These entities manage to beat the market.

As regards the $\mathrm{R}^{2}$, Hispania comes to the fore with a high value, which indicates that about $43 \%$ of the changes in SOCIMI return may be explained by changes in the market, as seen in the Ibex 35 . Colonial comes next, also with a high determination coefficient (0.375).

Table 5

Regresion results, Ibex35 and IGBM Inmo

\begin{tabular}{|c|c|c|c|c|c|}
\hline & $\alpha$ & Beta IBEX35 & Beta IGBM Inmo & $\mathrm{R}^{2}$ & $\mathrm{~N}^{\circ} \mathrm{OBS}$ \\
\hline \multirow[t]{2}{*}{ Axiare } & $\begin{array}{c}0,001 \\
(1,839)\end{array}$ & $\begin{array}{c}0,609 \\
(2,891) * * *\end{array}$ & & 0,173 & 42 \\
\hline & $\begin{array}{c}0,001 \\
(1,650)^{*}\end{array}$ & & $\begin{array}{c}0,651 \\
(3,177) * * *\end{array}$ & 0,202 & 42 \\
\hline \multirow[t]{2}{*}{ Lar } & $\begin{array}{c}0,000 \\
(0,793)\end{array}$ & $\begin{array}{c}0,510 \\
(3,174) * * *\end{array}$ & & 0,201 & 42 \\
\hline & $\begin{array}{l}0,0002 \\
(0,617)\end{array}$ & & $\begin{array}{c}0,464 \\
(2,988859) * *\end{array}$ & 0,213 & 42 \\
\hline \multirow[t]{2}{*}{ Hispania } & $\begin{array}{c}0,001 \\
(2,379)^{*}\end{array}$ & $\begin{array}{c}0,848 \\
(5,474) * * *\end{array}$ & & 0,428 & 42 \\
\hline & $\begin{array}{c}0,001 \\
(2,008)^{*}\end{array}$ & & $\begin{array}{c}0,814 \\
(5,187)^{* *}\end{array}$ & 0,402 & 42 \\
\hline Merlin & $\begin{array}{c}0,000 \\
(1,594)\end{array}$ & $\begin{array}{c}0,527 \\
(4,300)^{* * *}\end{array}$ & & 0,194 & 42 \\
\hline
\end{tabular}




\begin{tabular}{|c|c|c|c|c|c|}
\hline & $\alpha$ & Beta IBEX35 & Beta IGBM Inmo & $\mathrm{R}^{2}$ & $\mathrm{~N}^{\circ} \mathrm{OBS}$ \\
\hline & $\begin{array}{c}0,000 \\
(0.379)^{*}\end{array}$ & & $\begin{array}{c}0,565 \\
(3,429) * * *\end{array}$ & 0,227 & 42 \\
\hline Colonial & $\begin{array}{c}0,001 \\
(1,993)^{*} \\
0,001 \\
(2,219)^{* *}\end{array}$ & $\begin{array}{c}0,609 \\
(4,896)^{* * *}\end{array}$ & $\begin{array}{c}0,851 \\
(10,794)^{* * *}\end{array}$ & $\begin{array}{l}0,375 \\
0,744\end{array}$ & $\begin{array}{l}42 \\
42\end{array}$ \\
\hline Sur & $\begin{array}{c}0,001 \\
(0,965) \\
0,001 \\
(0,845) \\
\end{array}$ & $\begin{array}{c}0,454 \\
(1,063)\end{array}$ & $\begin{array}{c}0,650 \\
(1,560) \\
\end{array}$ & $\begin{array}{l}0,027 \\
0,057\end{array}$ & $\begin{array}{l}42 \\
42\end{array}$ \\
\hline Montebalito & $\begin{array}{c}0,001 \\
(1,970)^{*} \\
0,001 \\
(2,068)^{* *}\end{array}$ & $\begin{array}{c}1,045 \\
(3,039) * *\end{array}$ & $\begin{array}{c}0,928 \\
(2,600) \\
\end{array}$ & $\begin{array}{l}0,188 \\
0,145\end{array}$ & $\begin{array}{l}42 \\
42\end{array}$ \\
\hline Realia & $\begin{array}{c}0,000 \\
(0,104) \\
-0,000 \\
(0,293) \\
\end{array}$ & $\begin{array}{c}0,378 \\
(0,795)\end{array}$ & $\begin{array}{c}1,487 \\
(3,608) * * *\end{array}$ & $\begin{array}{l}0,016 \\
0,246\end{array}$ & $\begin{array}{l}42 \\
42\end{array}$ \\
\hline Renta Corporación & $\begin{array}{c}0,003 \\
(1,642) \\
0,004 \\
(1,552)\end{array}$ & $\begin{array}{c}0,076 \\
(0,093)\end{array}$ & $\begin{array}{c}0,594 \\
(0,736)\end{array}$ & $\begin{array}{l}0,000 \\
0,013\end{array}$ & $\begin{array}{l}42 \\
42\end{array}$ \\
\hline
\end{tabular}

Regarding the IGBM Inmo, the alphas of different SOCIMIs and Real estate companies (Axiare, Hispania, Merlin, Colonial, Montebalito and Renta Corporación), all present positive values, thus beating the market (IGBM Inmo), with fairly attractive returns.

As regards the goodness of fit of the titles mentioned in the previous paragraph, the quantity of the SOCIMIs and Colonial stand out. None of the $\mathrm{R}^{2}$ are lower than $20 \%$, especially Colonial with $74 \%$, resulting from its superior weight on the continuous market in terms of market capitalization.

The betas as a measure of systematic risk are significant in all the estimates carried out for the SOCIMIs both with the Ibex 35 and the IGBM Inmo. In all cases their values are positive and less than one, therefore they are defensive titles, which move in the same direction as the market but less intensely. Only two of the Real estate companies present significant betas with regard to the Ibex 35, Colonial and Montebalito, and another two with regard to the IGBM Inmo, Colonial and Realia. Colonial may be considered a defensive title since its beta is below one for both indeces. Montebalito is seen to be a slightly riskier value than the Ibex35; when the index varies around one unit, its value is a slightly higher percentage $(1,045)$. Realia is the one which shows the most aggresive behaviour of them all with a beta of 1,487 with the IGBM Inmo. 
Generally it can be concluded that the SOCIMIs have a greater return than the market while supposing less risk. Some Real estate companies manage to beat the market, as they present interesting positive Jensen's alpha, although they assume higher risk than the SOCIMIs.

\subsection{Study of the SOCIMIs risk diversification}

Following Markowitz's Model to determine efficient frontiers and choosing the approach to minimize risk for different returns, Solver and Solver Table are used for expected returns, standard deviations and covariances for both the SOCIMIs and Real estate companies.

Firstly the four SOCIMIs are introduced in the analysis. Figure 6 contains the results. It can be seen how the efficient frontier wraps the SOCIMIs offering dominant portfolios with less risk for the same return or greater return for a determined level of risk.

Figure 6

\section{Efficient frontier SOCIMIs}

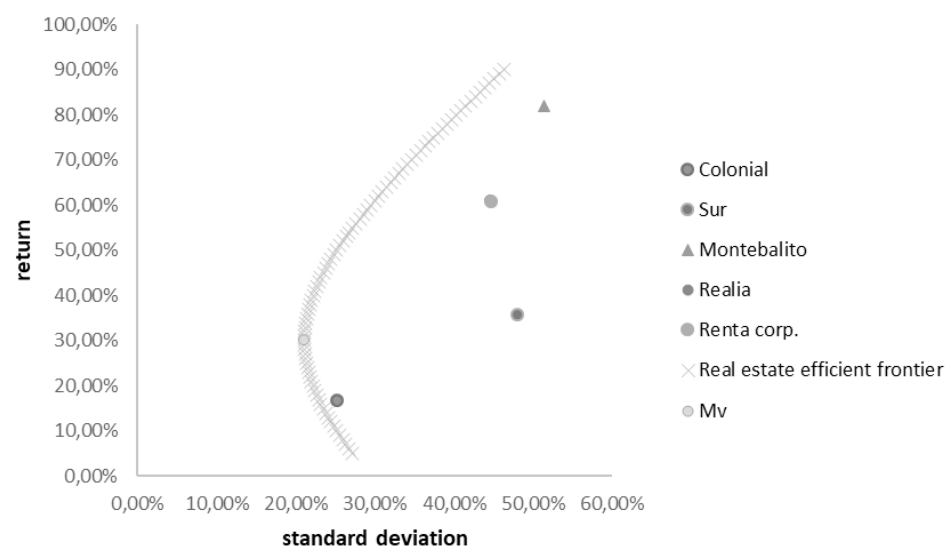

Source: Authors, data from Infobolsa.

Concentrating on the efficient line (from the portfolio with the minimum variance -Mvto the higher area of the frontier), an important increase in return can be observed when combining different assets, compared with the one reached by investing in any title individually. The portfolio with minimum variance (Mv) implies $16,58 \%$ risk and offers $20,18 \%$ annual return, which would be obtained by investing $29,03 \%$ in Axiare, 16,81\% in Lar, 43,36\% in Hispania and 10,81\% in Merlin.

Next the same analysis for Real estate companies will be carried out. Figure 7 shows the efficient frontier obtained. 
Figure 7

Efficient frontier Real estate companies

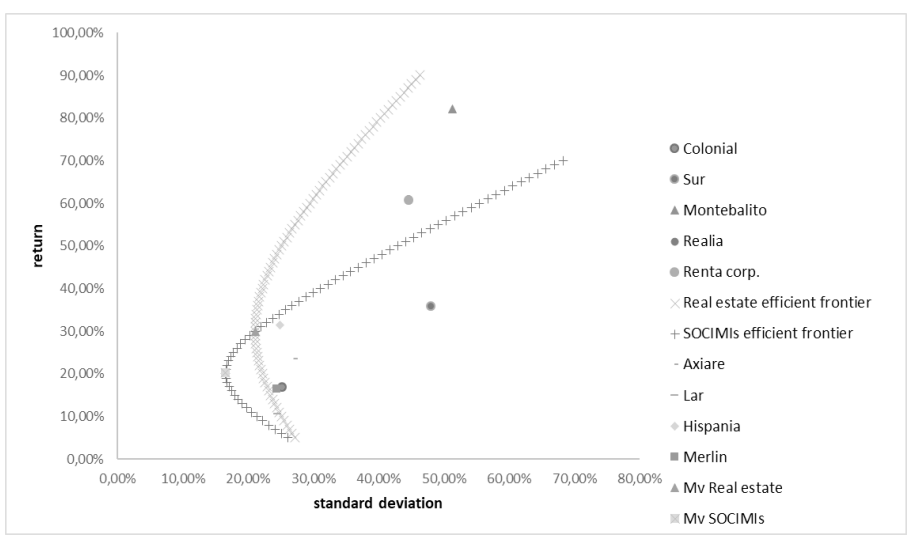

Source: Authors, data from Infobolsa.

In the previous figure great potential for diversification can be seen for Real estate companies. Working with a risk level of around 50\%, as in the case of Inmobiliaria del Sur, which obtains $37 \%$ return, by combining all the Real estate companies, a portfolio can be obtained that for the same risk, offers $85 \%$ annual return.

Consequently two previous efficient frontiers have been joined in Figure 8. A change in the dominance of the frontiers according to the level of risk analyzed can be seen. Up to risk levels of 25\%, the efficient part of the SOCIMIs' curve dominates the Real estate companies one, which changes above the risk level previously mentioned.

Figure 8

\section{SOCIMIs and Real estate companies efficient frontiers}

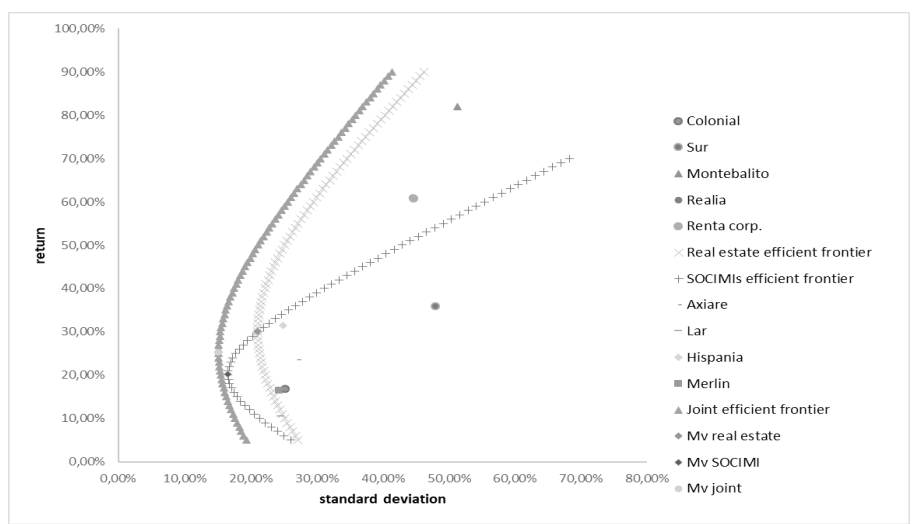

Source: Authors, data from Infobolsa. 
The SOCIMIs run much less risk than the Real estate companies, and so are much more to the left in individual terms, which makes their combinations as well as the minimum variance porfolio further to the left than in the case of the Real estate companies.

Now the joint efficient frontier is determined i. e. using the SOCIMIs and Real estate companies as the asset universe. The results are shown in Figure 9.

Figure 9

Efficient frontier of SOCIMIs, Real estate companies and together

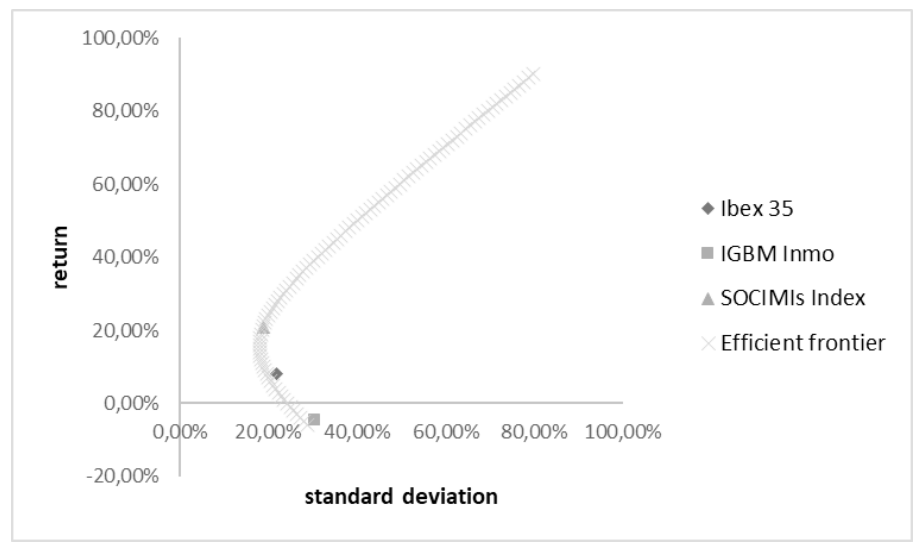

Source: Authors, data from Infobolsa.

It must be pointed out that the diversifying potential of these two investment vehicles has clearly increased. As can be seen, the green line (joint efficient frontier) clearly dominates the individual frontiers, as well as the isolated titles.

Finally (Figure 10), to look more deeply into the diversifying of this type of real estate investment, the efficient frontier combined between the following three indeces: Ibex 35, SOCIMIs index (author's compilation) and IGBM Inmo. This type of investment strategy through indeces is easily replicable nowadays is shown.

To elaborate the SOCIMI index, a weighted average of the monthly profitability of the four SOCIMIs has been calculated, weighted by the market capitalization of each one with respect to the total at present. The following formula was used:

$$
\text { SOCIMIs Index }=\sum_{\mathrm{i}=1}^{4} \mathrm{r}_{\mathrm{it}} \times \frac{\mathrm{p}_{\mathrm{it} \times} \mathrm{q}_{\mathrm{it}}}{\sum_{\mathrm{i}=1}^{4} \mathrm{p}_{\mathrm{it} \times} \mathrm{q}_{\mathrm{it}}}
$$

In Figure 10, the position of the SOCIMIs index individually can be highlighted, which manages to individually dominate the rest, as it offers the greatest return, subject to a smaller risk. Looking at the efficient line of the curve, it can be emphasized that by joining the three indices, a small diversifying effect is obtained in our portfolio, considering as such the one which represents the SOCIMIs Index. Indeces, being compiled by different titles, are, by nature, diversified, which leads to a small diversifying effect when they are combined. 
Figure 10

\section{Efficient frontier indeces}

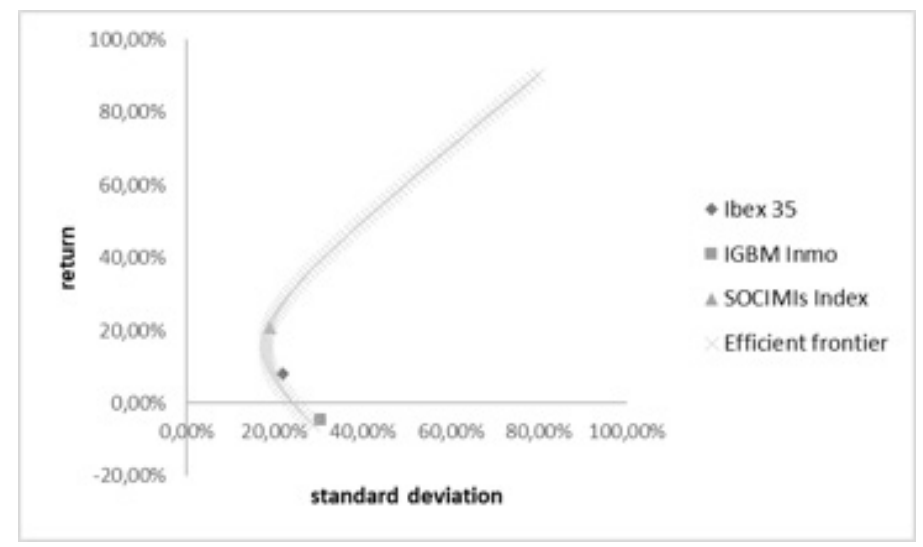

Source: Authors, data from Infobolsa.

Joining only the Ibex 35 and the SOCIMIs Index, another efficient frontier is produced (Figure 11). In this case the minimum variance portfolio carries a risk of $18,07 \%$ for a $16,76 \%$ return and $30,87 \%$ should be invested on the Ibex and the rest in the SOCIMIs Index.

Figure 11

\section{Ibex35 - SOCIMIs index efficient frontier}

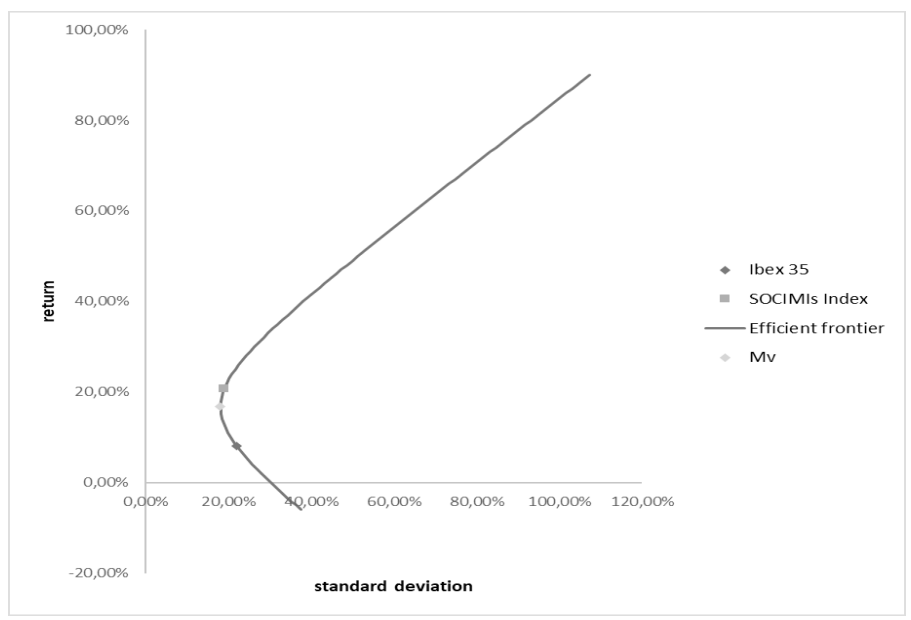

Source: Authors, data from Infobolsa.

In Figure 11, net purchases has a small stretch, from the Ibex 35 to the SOCIMIs Index since the greater part of the curve would correspond to short sales for the Ibex 35 . This 
result is logical as the SOCIMIs Index dominates the Ibex 35 one. The aforementioned spot efficient frontier would be found between the Mv portfolio and the SOCIMIs Index.

\section{CONCLUSIONS}

After the crisis suffered by the real estate sector and the great distrust which it caused, in recent years, considering indications such as volume of investment in land, rate of sales and price level, it leads us to think of recovery and good perspectives for the future. This situation is enhanced by the popularity of the SOCIMIs on the markets, which, thanks to their higher incentives, their professional management and the high level of dividends offered, they manage to inject greater liquidity into a market historically dominated by scarcity.

In order to widen the knowledge of the SOCIMIs in Spain, their performance and potential for diversification, were analyzed, mainly concentrating on the four entities on the continuous market, which were then compared to the traditional Real estate companies. As regards performance, analyzed using Modified Sharpe Ratio and Jensen's alpha, both the SOCIMIs as well as the Real estate companies, achieved very poor results in 2014. Greater return of the one year Spanish Treasury bond, as well as the low return offered by the titles themselves, dragged down the sector which hardly saw the light after the major crisis it experienced. 2015 onwards, with the lowering of bond interest and increase in the return from the real estate sector, saw the increase in the ratio and in 2017 it rose sharply.

Jensen's alpha shows similar results, the SOCIMIs enjoy a higher yield than the market with smaller risk than the market itself. Some Real estate companies also manage to beat the market with interesting positive Jensen's alphas, although generally implying greater risk than the SOCIMIs. This improved SOCIMIs' situation is also confirmed by analysing the dividend yield, ROE, ROA, solvency and leverage ratios.

As regards the diversifying effect, by using the efficient frontiers it can be emphasized that both the SOCIMIs and the Real estate companies offer combinations, portfolios, which are very appealing to any investor. By making a comparison between both frontiers, the domination of the SOCIMs in relatively low risk values can be seen, leaving the traditional Real estate companies for investors with less risk aversion. This aspect clearly demonstrates the lower risk presented by the SOCIMIs we mentioned at the beginning.

Lastly an index has been made up with the four SOCIMIs on the continuous market. This index has been combined with the Ibex 35 and with the IGBM Inmo, where the domination over the other two is perfectly clear. This fact corroborates the importance of the diversifying effect which can be achieved with the SOCIMIs, and ultimately with real estate investment through these vehicles.

At present it is simple for any investor to follow a passive strategy of indexing or replication of an index. This is a common policy in our times for the majority of investors. The present study leads us to believe that, in the short and medium term, the SOCIMIs will maintain a steady growth and will easily attract investment assets with great potential for diversifying portfolios. 


\section{REFERENCES}

BME, 2015. Informe de mercado 2015. Available in https://www.bolsasymercados.es/esp/ Estudios-Publicaciones/Informe-Mercado/2015 (04/04/2017)

BME, 2016. Informe de mercado 2016. Available in https://www.bolsasymercados.es/esp/ Estudios-Publicaciones/Informe-Mercado/2016 (04/04/2017)

BME, 2017. Informe de mercado 2017. Available in https://www.bolsasymercados.es/esp/ Estudios-Publicaciones/Informe-Mercado/2017 (12/10/2018)

Boletín Oficial del Estado, 2009. Ley 11/2009, de 26 de octubre, por la que se regulan las Sociedades Anónimas Cotizadas de Inversión en el Mercado Inmobiliario, Madrid: BOE.

Boletín Oficial del Estado, 2012. Ley 16/2012, de 27 de diciembre, por la que se adoptan diversas medidas tributarias dirigidas a la consolidación de las finanzas públicas y al impulso de la actividad económica, Madrid: BOE.

Fernández, N., and Romero, M., 2016. Las Socimi y el mercado inmobiliario. Cuadernos de Información económica, (253), 61-66.

Ferruz Agudo, L. and Sarto Marzal, J. L., 2004. An analysis of Spanish investment fund performance: some considerations concerning Sharpe's ratio. Omega, The International Journal of Management Science, 32, 273-284.

Israelsen, C. L., 2003. Sharpening the Sharpe ratio. Financial Planning, 33, 49-51.

Israelsen, C. L., 2005. A refinement to the Sharpe ratio and information ratio. Journal of Asset Management 5, 423-427.

López Penabad, M. C., López Andión, C., and Maside-Sanfiz, J. M., 2006. Los fondos de inversión inmobiliaria en España 1994-2005: Análisis del rendimiento y persistencia. Regional and Sectoral Economic Studies, 6 (2), 73-100.

Markowitz, H., 1952. Portfolio Selection. The Journal of Finance, 7 (1), 77-91.

Maside-Sanfiz, J.M., Iglesias Casal, A., López Penabad, M.C. and López Andión, C., 2016. Eficiencia y Persistencia de los Fondos de inversión inmobiliaria en España. Cuadernos de Gestión, 16 (2), 147-166. DOI: 10.5295/cdg.140497ml

Roig Hernando, J., and Soriano Llobera, M., 2015. Liquidez y cotización respecto al valor neto de los activos de los REITespañoles (las SOCIMI). Revista Europea de Dirección y Economía de la Empresa, 24, 92-107. DOI: 10.1016/j.redee.2014.09.005 


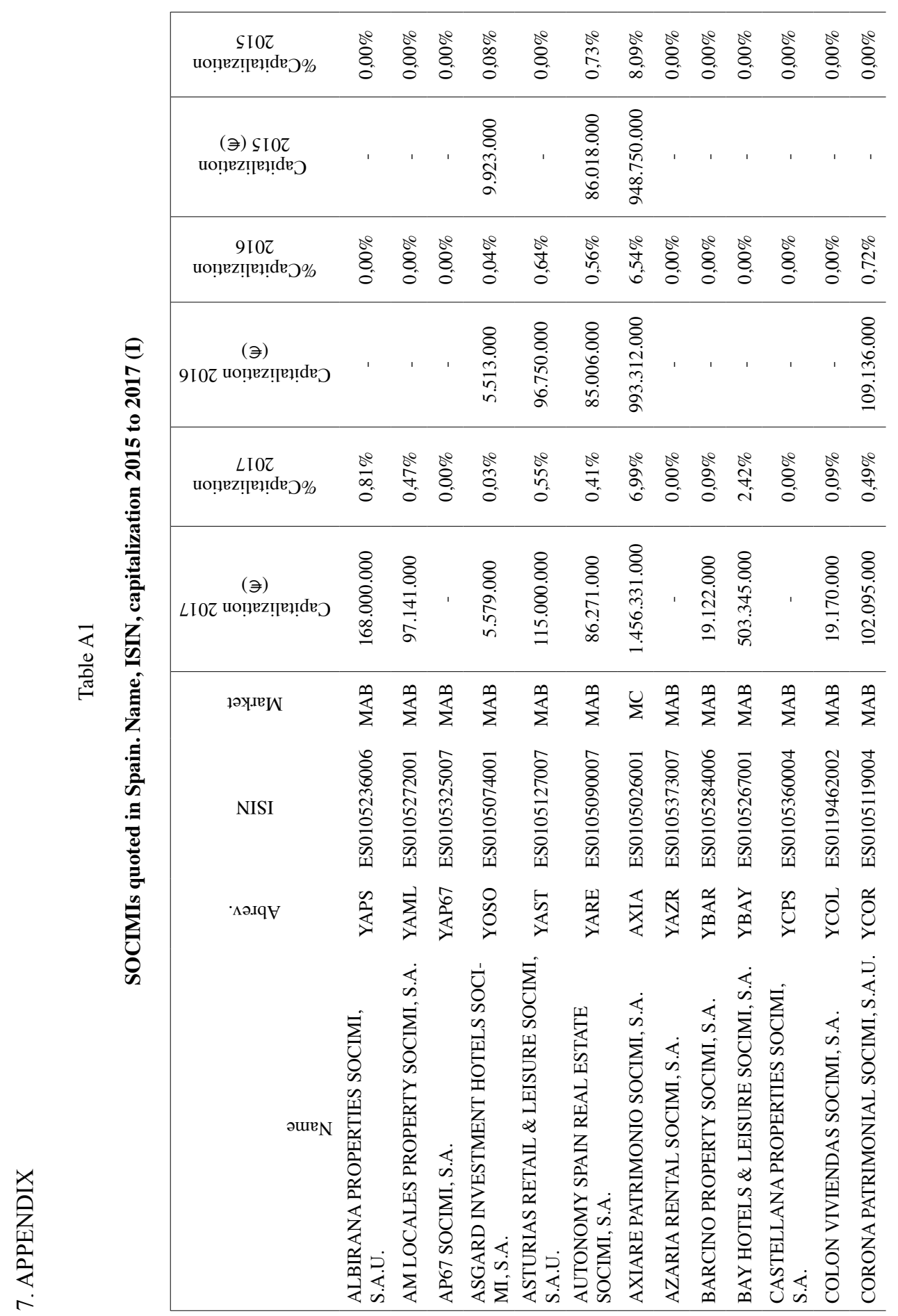




\begin{tabular}{|c|c|c|c|c|c|c|c|c|c|c|c|c|c|c|c|c|c|c|c|}
\hline 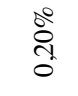 & $\begin{array}{l}8 \\
8 \\
0\end{array}$ & 8 & ठ̊. & $\begin{array}{l}8 \\
8 \\
0\end{array}$ & 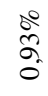 & 0 & $\stackrel{8}{8}$ & & $\begin{array}{l}8 \\
8 \\
8 \\
0\end{array}$ & $\stackrel{8}{8}_{0}$ & $\begin{array}{l}0 \\
8 \\
0\end{array}$ & $0^{\circ}$ & $\begin{array}{l}\text { oे } \\
\text { ठ. }\end{array}$ & $\begin{array}{l}80 \\
8 \\
8 \\
0\end{array}$ & 8̊ & ঠ̊ & & 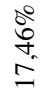 & \\
\hline 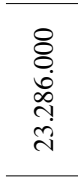 & ' & ' & ' & ' & $\begin{array}{l}\dot{\sigma} \\
\vec{\sigma} \\
\infty\end{array}$ & ' & ' & $\begin{array}{l}8 \\
8 \\
\stackrel{0}{0} \\
\text { ì } \\
\text { i }\end{array}$ & & ' & ' & ' & 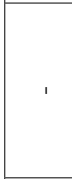 & & & & సે & 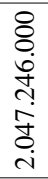 & \\
\hline$\frac{\stackrel{0}{n}}{\stackrel{0}{0}}$ & $\frac{\stackrel{0}{0}}{0}$ & 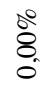 & $\begin{array}{l}8 \\
8 \\
0\end{array}$ & $\begin{array}{l}0 \\
8 \\
0\end{array}$ & స్ర & $\underset{\sigma}{\sigma}$ & $\begin{array}{l}80 \\
8 \\
0 \\
0\end{array}$ & $\approx$ & $\begin{array}{l}\circ \\
8 \\
0 \\
0\end{array}$ & $\begin{array}{l}\text { ले } \\
\text { in }\end{array}$ & $\begin{array}{l}0 \\
8 \\
0\end{array}$ & 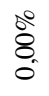 & $\varepsilon$ & 8 & 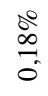 & $\sim$ & & is & $\begin{array}{l}\text { N. } \\
\text { o. }\end{array}$ \\
\hline 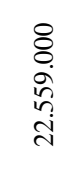 & $\begin{array}{l}\stackrel{8}{8} \\
\dot{0} \\
\stackrel{+}{+} \\
\stackrel{n}{n}\end{array}$ & 1 & ' & ' & $\begin{array}{l}8 \\
8 \\
\dot{0} \\
\dot{\infty} \\
0 \\
\dot{0} \\
0\end{array}$ & $\begin{array}{l}8 \\
8 \\
8 \\
8 \\
i n \\
i n\end{array}$ & ' & 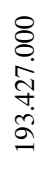 & & 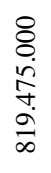 & ' & , & & ' & 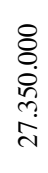 & 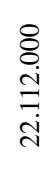 & $\stackrel{\vec{g}}{\stackrel{m}{g}}$ & 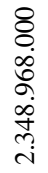 & $\begin{array}{l}0 \\
\dot{j} \\
\infty \\
\infty \\
\infty \\
\infty\end{array}$ \\
\hline $\begin{array}{l}\stackrel{\circ}{=} \\
0\end{array}$ & 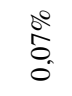 & $\begin{array}{l}\circ \\
\vdots \\
0\end{array}$ & $\begin{array}{l}\frac{0}{2} \\
i n \\
0\end{array}$ & $\begin{array}{l}0 \\
8 \\
0\end{array}$ & $\stackrel{\stackrel{0}{\sigma}}{\stackrel{\sigma}{0}}$ & $\stackrel{\stackrel{\circ}{ }}{ }$ & $\begin{array}{l}8 \\
8 \\
8 \\
0\end{array}$ & $\stackrel{\circ}{\check{\infty}}$ & $\begin{array}{l}\circ \\
8 \\
0\end{array}$ & $\begin{array}{l}\stackrel{0}{\circ} \\
\stackrel{2}{\circ} \\
\stackrel{+}{*}\end{array}$ & 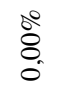 & $\stackrel{\circ}{i n}$ & 8 & $\therefore$ & 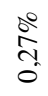 & $=$ & & $\vec{m}$ & $\frac{\stackrel{0}{0}}{0}$ \\
\hline $\begin{array}{l}8 \\
8 \\
\hat{n} \\
\hat{n} \\
\tilde{n}\end{array}$ & $\begin{array}{l}8 \\
\delta \\
n \\
n \\
n \\
n \\
n\end{array}$ & $\begin{array}{l}\stackrel{8}{8} \\
\stackrel{+}{+} \\
\stackrel{1}{r}\end{array}$ & $\begin{array}{l}8 \\
8 \\
\ddot{n} \\
a \\
= \\
=\end{array}$ & ' & $\begin{array}{l}8 \\
0 \\
\dot{0} \\
+ \\
\infty \\
\infty \\
\infty\end{array}$ & $\begin{array}{l}8 \\
8 \\
8 \\
8 \\
0 \\
n \\
n\end{array}$ & 1 & $\begin{array}{l}8 \\
8 \\
0 \\
\infty \\
n \\
n\end{array}$ & & $\stackrel{0}{i}$ & ' & $\begin{array}{l}8 \\
8 \\
\circ \\
\sigma\end{array}$ & 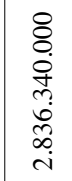 & $\begin{array}{l}8 \\
8 \\
\stackrel{2}{m} \\
m \\
\stackrel{r}{r}\end{array}$ & $\begin{array}{l}8 \\
8 \\
8 \\
8 \\
\dot{8} \\
\dot{\circ}\end{array}$ & $\frac{\bar{a}}{\mathrm{~m}}$ & 7 & $\begin{array}{l}0 \\
\stackrel{+}{0} \\
\stackrel{0}{\circ} \\
\stackrel{0}{0}\end{array}$ & $\begin{array}{l}\text { o. } \\
\infty \\
\infty \\
\text { m. } \\
\text { m. }\end{array}$ \\
\hline$\sum$ & $\sum$ & 2 & $\sum_{\Sigma}^{\infty}$ & 2 & & 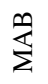 & $z$ & & $\sum$ & & & & & & 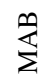 & & & $\dot{\Sigma}$ & 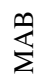 \\
\hline 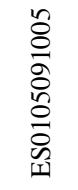 & 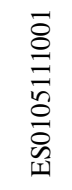 & 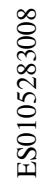 & $\begin{array}{l}8 \\
0 \\
0 \\
\text { ñ } \\
0 \\
0 \\
0 \\
\text { nิ }\end{array}$ & 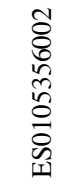 & 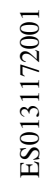 & 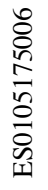 & 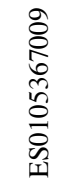 & 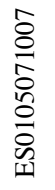 & 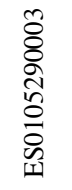 & 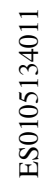 & 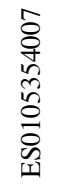 & 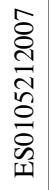 & $\frac{o}{n}$ & 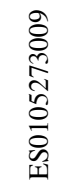 & 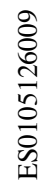 & 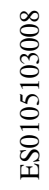 & 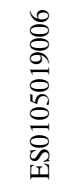 & 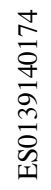 & 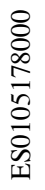 \\
\hline$\frac{\overparen{2}}{2}$ & $\stackrel{\overbrace{}}{\stackrel{2}{2}}$ & $\sum$ & 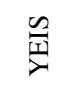 & J & 5 & 号 & 8 & & 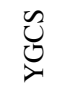 & 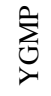 & $\begin{array}{l}0 \\
0 \\
0\end{array}$ & 禾 & 8 & & 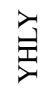 & 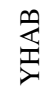 & & $\overrightarrow{0}$ & $\sum$ \\
\hline 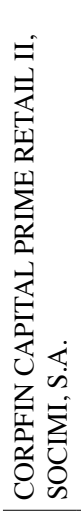 & 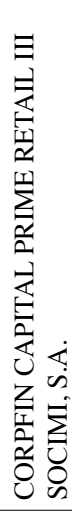 & 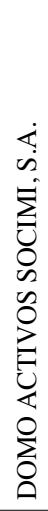 & 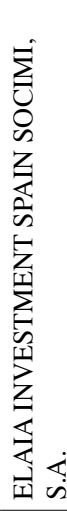 & 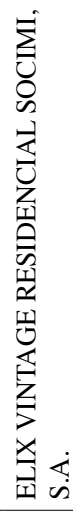 & 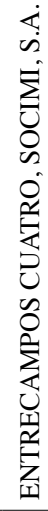 & 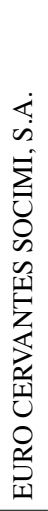 & 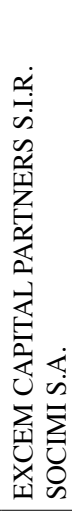 & 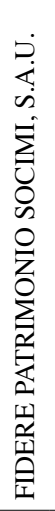 & 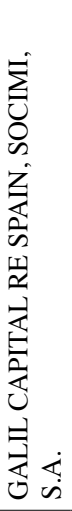 & 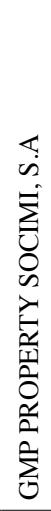 & 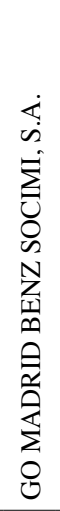 & 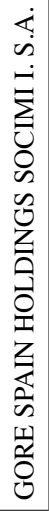 & 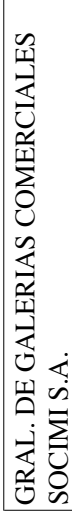 & 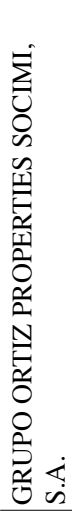 & 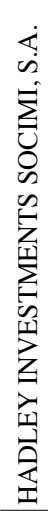 & 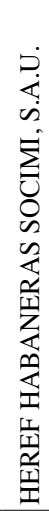 & 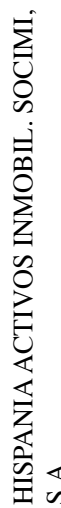 & 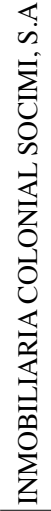 & 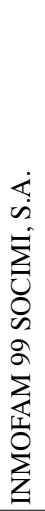 \\
\hline
\end{tabular}




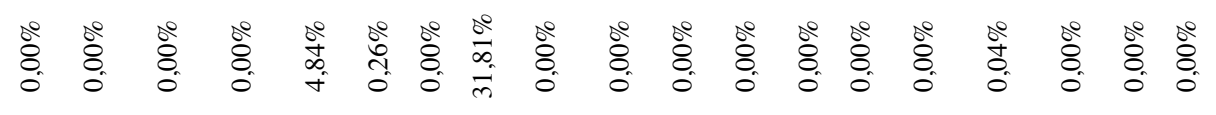

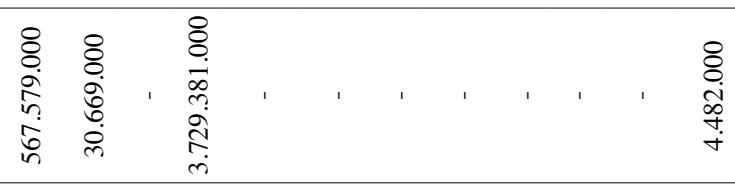

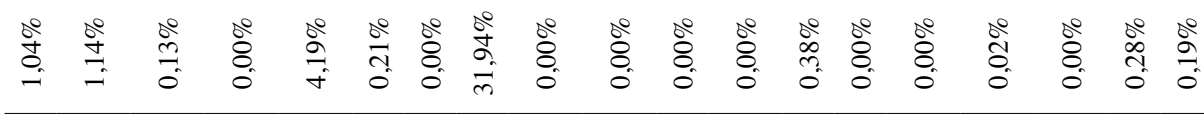

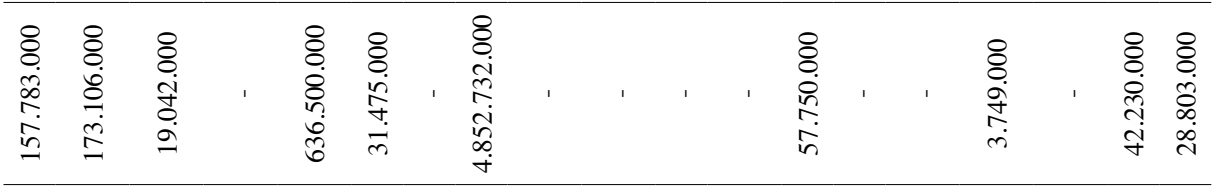

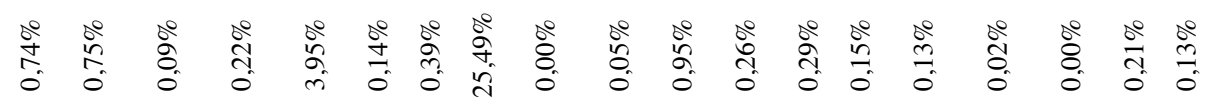

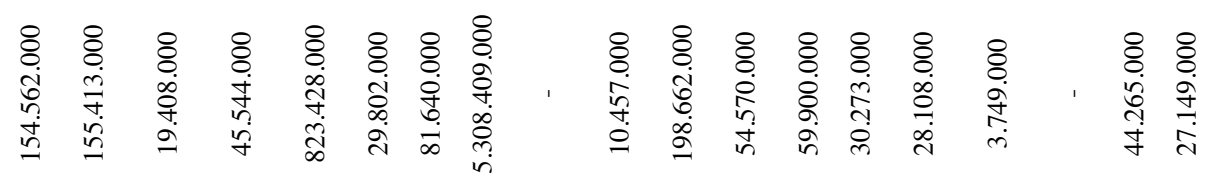

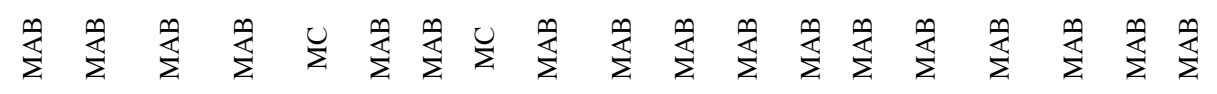

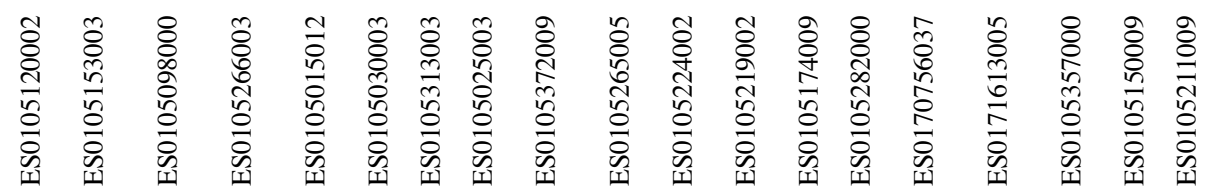

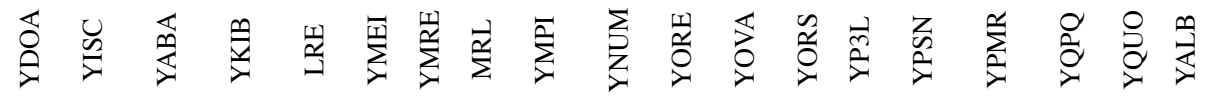

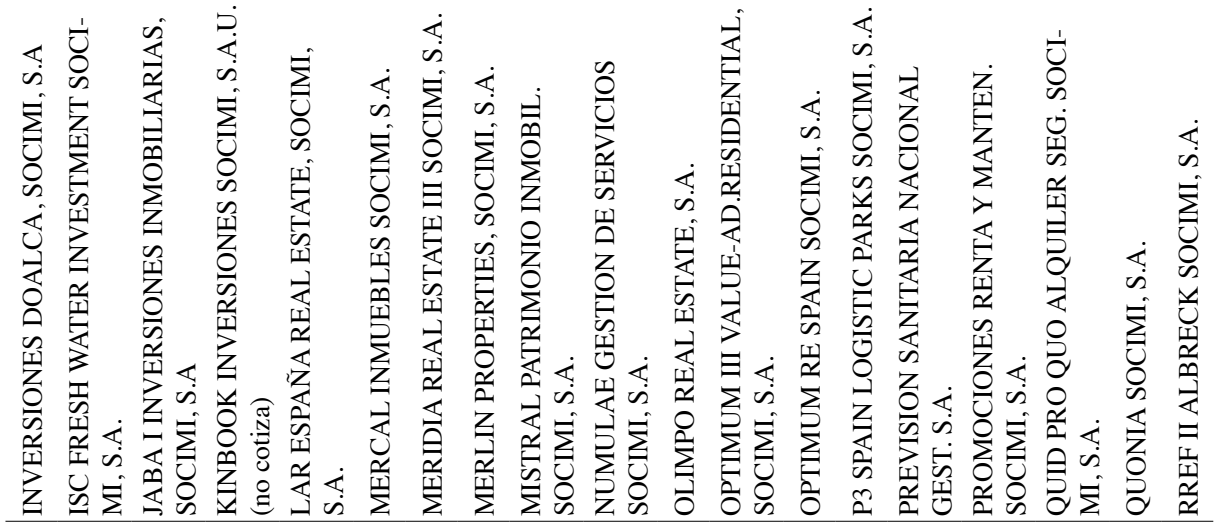




\begin{tabular}{|c|c|c|c|c|c|c|c|c|c|c|c|c|c|c|c|c|c|c|c|}
\hline $\begin{array}{l}80 \\
8 \\
0\end{array}$ & $\begin{array}{l}8 \\
8 \\
0\end{array}$ & $\begin{array}{l}8 \\
8 \\
0\end{array}$ & $\left|\begin{array}{c}0 \\
8 \\
8 \\
0\end{array}\right|$ & $\left|\begin{array}{l}0 \\
8 \\
0 \\
0\end{array}\right|$ & $\begin{array}{l}8 \\
8 \\
0 \\
0\end{array}$ & $\begin{array}{l}80 \\
8 \\
0 \\
0\end{array}$ & 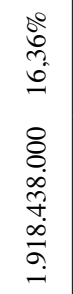 & $\begin{array}{l}80 \\
8 \\
0 \\
0\end{array}$ & 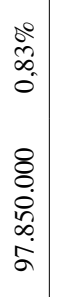 & $\begin{array}{l}80 \\
8 \\
0\end{array}$ & $\begin{array}{l}\stackrel{0}{0} \\
\infty \\
- \\
- \\
8 \\
\infty \\
\infty \\
0 \\
\infty \\
\infty \\
\vec{\sim}\end{array}$ & $\begin{array}{l}\stackrel{0}{8} \\
8 \\
0\end{array}$ & $\begin{array}{l}80 \\
8 \\
8 \\
0\end{array}$ & $\begin{array}{l}80 \\
8 \\
0 \\
0\end{array}$ & 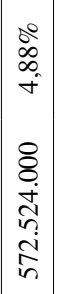 & $\begin{array}{l}\frac{8}{2} \\
i \\
0 \\
8 \\
8 \\
8 \\
8 \\
m \\
0 \\
0\end{array}$ & 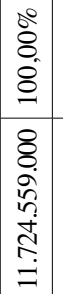 & 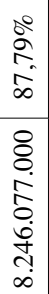 & 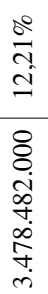 \\
\hline$\stackrel{80}{8}$ & 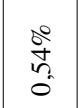 & $\ddot{8}_{0}^{\circ}$ & $\left|\begin{array}{l}0 \\
8 \\
8 \\
0\end{array}\right|$ & $\mid \begin{array}{l}0 \\
8 \\
0 \\
0\end{array}$ & $\begin{array}{l}80 \\
8 \\
0\end{array}$ & $\begin{array}{l}80 \\
8 \\
0 \\
0\end{array}$ & $\begin{array}{l}8 \\
\stackrel{0}{0} \\
\text { a }\end{array}$ & $\begin{array}{l}80 \\
8 \\
0\end{array}$ & $\begin{array}{l}\stackrel{0}{0} \\
\stackrel{0}{0} \\
\stackrel{0}{0}\end{array}$ & $\begin{array}{l}80 \\
8 \\
0\end{array}$ & $\begin{array}{l}\stackrel{0}{0} \\
\text { ㄱ. }\end{array}$ & $\frac{\frac{5}{ \pm}}{0}$ & $\begin{array}{l}0 \\
8 \\
8 \\
0\end{array} \mid$ & $\begin{array}{l}\stackrel{\circ}{\hat{\theta}} \\
\hat{n} \\
0\end{array}$ & $\mid \begin{array}{c}0 \\
0 \\
0 \\
0 \\
\infty\end{array}$ & $\begin{array}{l}b^{\circ} \\
\stackrel{+}{+} \\
0\end{array}$ & \begin{tabular}{|l|}
80 \\
8 \\
8 \\
8
\end{tabular} & $\begin{array}{l}\stackrel{0}{\Xi} \\
\frac{\infty}{\infty}\end{array}$ & $\begin{array}{l}\stackrel{0}{0} \\
\infty \\
\dot{N} \\
\vec{N}\end{array}$ \\
\hline ' & 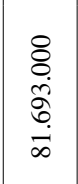 & ' & ' & ' & ' & ' & 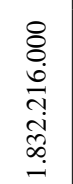 & ' & 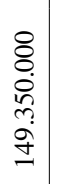 & ' & 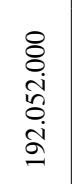 & 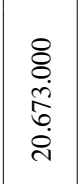 & I & $\begin{array}{l}8 \\
8 \\
\stackrel{0}{0} \\
\stackrel{0}{1} \\
\dot{+}\end{array}$ & $\begin{array}{l}8 \\
8 \\
8 \\
8 \\
8 \\
0 \\
i n\end{array}$ & 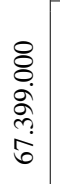 & 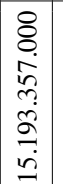 & 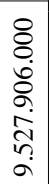 & 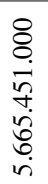 \\
\hline $\begin{array}{l}8 \\
8 \\
8 \\
0\end{array}$ & $\begin{array}{l}\stackrel{\circ}{0} \\
\text { ले } \\
0\end{array}$ & : & $\begin{array}{l}0 \\
8 \\
8 \\
0 \\
0\end{array}$ & $\left|\begin{array}{l}0 \\
0 \\
0 \\
0 \\
0\end{array}\right|$ & $\begin{array}{l}8 \\
8 \\
0\end{array}$ & $\begin{array}{l}8 \\
8 \\
8 \\
0\end{array}$ & $\begin{array}{l}\stackrel{0}{8} \\
8 \\
0\end{array}$ & $\begin{array}{l}8_{0}^{\circ} \\
8 \\
0\end{array}$ & $\frac{\stackrel{8}{\circ}}{\stackrel{0}{0}}$ & $\begin{array}{l}80 \\
8 \\
8 \\
0\end{array}$ & $\begin{array}{l}\stackrel{0}{\infty} \\
\infty \\
\infty \\
0\end{array}$ & $\frac{\stackrel{0}{J}}{0}$ & $\begin{array}{l}8_{0}^{\circ} \\
8 \\
0 \\
0\end{array}$ & $\begin{array}{l}\stackrel{0}{0} \\
m \\
0 \\
0\end{array}$ & 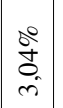 & $\begin{array}{l}\stackrel{0}{0} \\
\stackrel{+}{+} \\
0\end{array}$ & $\begin{array}{l}8 \\
8 \\
8 \\
8 \\
0\end{array}$ & 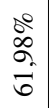 & $\begin{array}{l}\stackrel{\circ}{0} \\
\text { o } \\
\infty \\
\infty\end{array}$ \\
\hline ' & 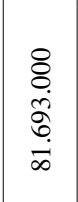 & 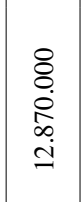 & ' & $\begin{array}{l}\delta \\
\delta \\
\dot{n} \\
\tilde{\sigma} \\
\sigma \\
\sigma\end{array}$ & I & ' & ' & ' & $\begin{array}{l}8 \\
\delta \\
\dot{m} \\
\stackrel{2}{0} \\
\stackrel{n}{n}\end{array}$ & ' & $\begin{array}{l}8 \\
\delta \\
\dot{0} \\
\infty \\
\infty \\
\infty\end{array}$ & 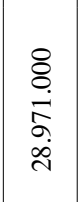 & ' & $\begin{array}{l}8 \\
\delta \\
\infty \\
\hat{0} \\
\infty \\
\infty \\
0\end{array}$ & 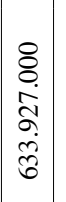 & $\begin{array}{l}8 \\
8 \\
\dot{8} \\
\stackrel{1}{1} \\
0 \\
0\end{array}$ & 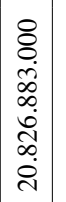 & 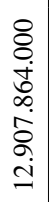 & 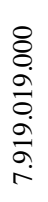 \\
\hline$\sum_{\Sigma}^{\infty}$ & $\sum_{\Sigma}^{\infty}$ & $\sum_{\Sigma}^{\infty}$ & $\sum_{\Sigma}^{\infty}$ & $\sum_{\Sigma}^{\infty}$ & $\sum_{\Sigma}^{\infty}$ & $\sum_{\Sigma}^{\infty}$ & $\sum$ & $\sum_{\Sigma}^{\infty}$ & $\sum_{\Sigma}^{\infty}$ & $\sum_{\Sigma}^{\infty}$ & $\sum_{i}^{\infty}$ & $\sum_{i}^{\infty}$ & $\sum_{\Sigma}^{\infty}$ & $\sum_{\Sigma}^{\infty}$ & $\sum_{\Sigma}^{\infty}$ & $\sum_{\Sigma}^{\infty}$ & స్ّ & $\sum_{\Sigma}^{U}$ & $\stackrel{\infty}{\Sigma}$ \\
\hline 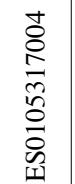 & 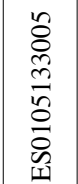 & 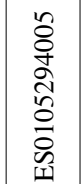 & 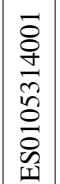 & 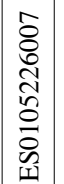 & 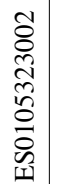 & 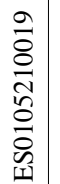 & 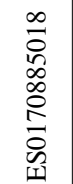 & 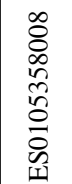 & 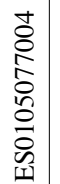 & 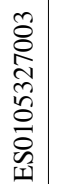 & 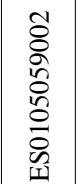 & 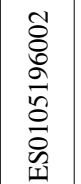 & 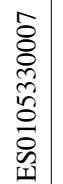 & 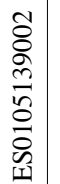 & 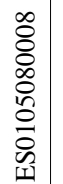 & 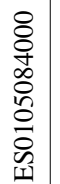 & & & \\
\hline 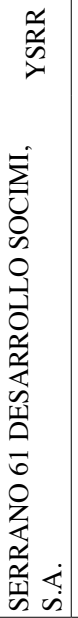 & 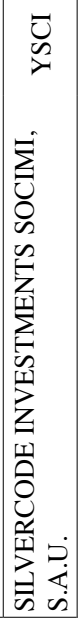 & 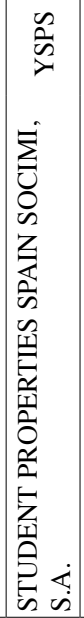 & 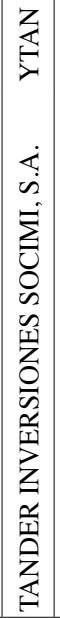 & 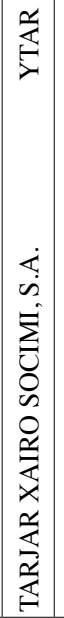 & 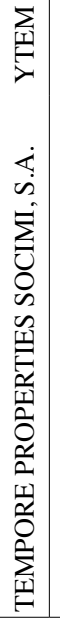 & 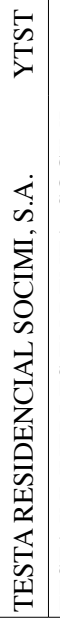 & 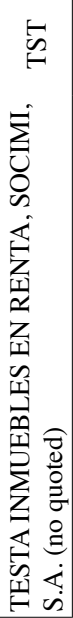 & 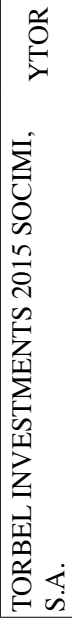 & 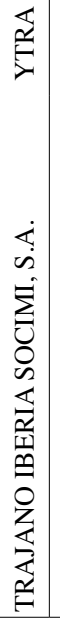 & 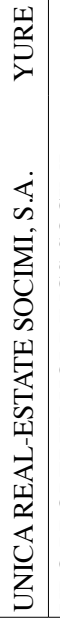 & 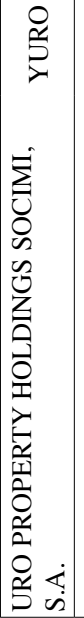 & 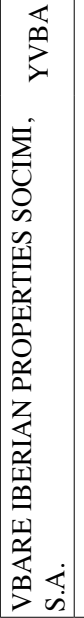 & 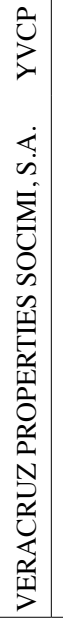 & 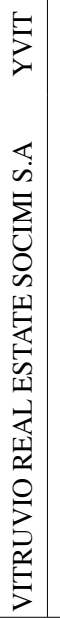 & 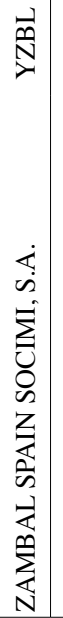 & 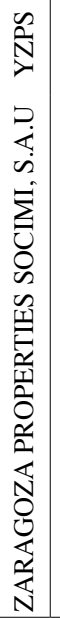 & & & \\
\hline
\end{tabular}




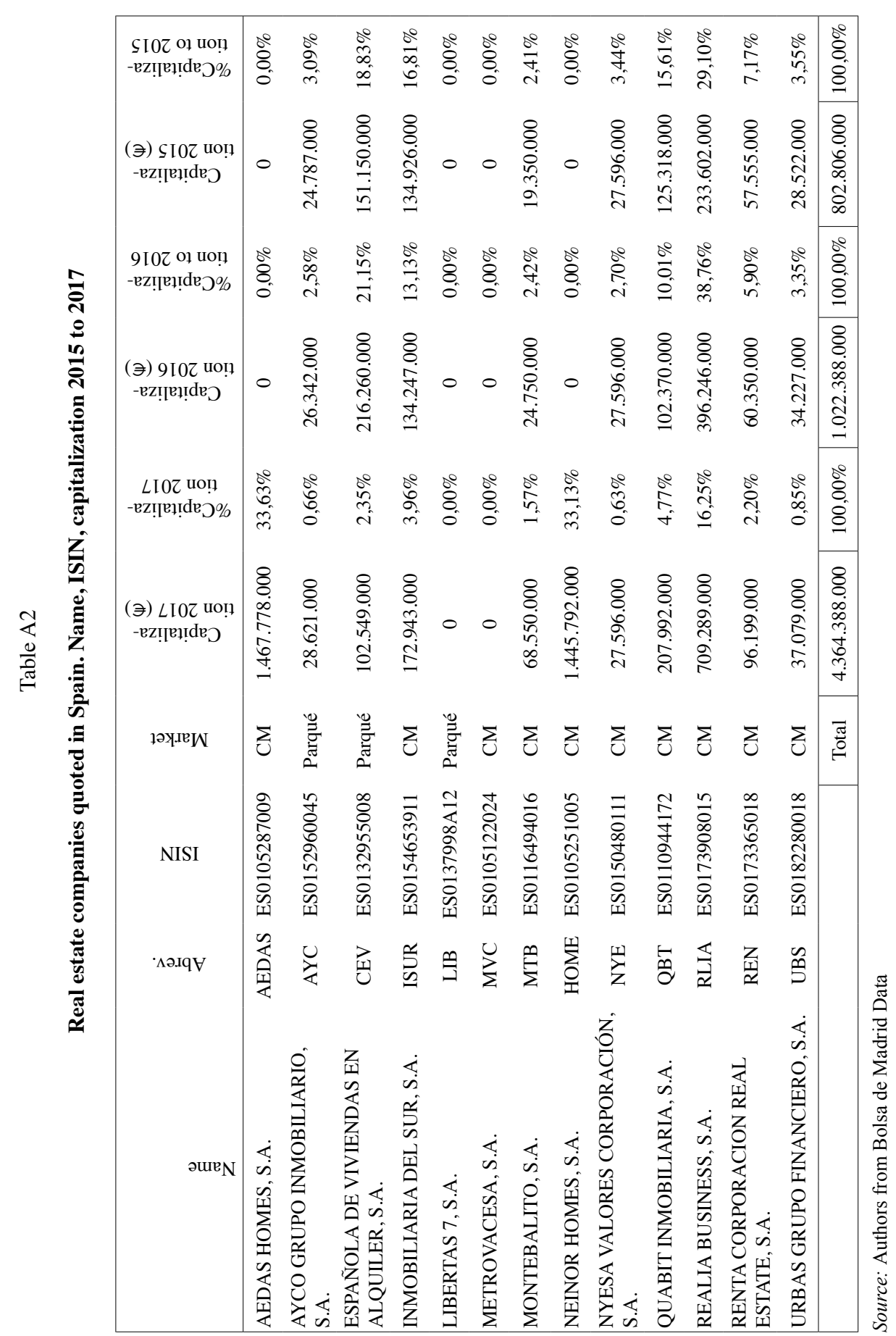


Table A3

Descriptive statistics of daily return series

\begin{tabular}{|c|c|c|c|c|c|c|}
\hline & Axiare & Hispania & Lar & Merlin & Ibex35 & Ind. Inm. \\
\hline Mean & $0,09 \%$ & $0,07 \%$ & $0,03 \%$ & $0,03 \%$ & $0,00 \%$ & $0,03 \%$ \\
\hline Typical error & $0,06 \%$ & $0,05 \%$ & $0,05 \%$ & $0,05 \%$ & $0,04 \%$ & $0,04 \%$ \\
\hline Median & $0,00 \%$ & $0,00 \%$ & $0,00 \%$ & $0,05 \%$ & $0,05 \%$ & $0,07 \%$ \\
\hline Mode & $0,00 \%$ & $0,00 \%$ & $0,00 \%$ & $0,00 \%$ & - & $0,00 \%$ \\
\hline Standard deviation & $1,67 \%$ & $1,50 \%$ & $1,48 \%$ & $1,53 \%$ & $1,31 \%$ & $1,27 \%$ \\
\hline Variance & $0,03 \%$ & $0,02 \%$ & $0,02 \%$ & $0,02 \%$ & $0,02 \%$ & $0,02 \%$ \\
\hline Curtosis & 6,56 & 11,22 & 6,58 & 16,97 & $956,68 \%$ & $991,24 \%$ \\
\hline Asymmetry coefficient & 0,63 & $-0,90$ & $-0,14$ & $-1,94$ & $-105,84 \%$ & $-100,40 \%$ \\
\hline Range & $20,35 \%$ & $21,15 \%$ & $20,05 \%$ & $20,74 \%$ & $16,23 \%$ & $16,40 \%$ \\
\hline Minimum & $-7,95 \%$ & $-14,53 \%$ & $-11,28 \%$ & $-14,91 \%$ & $-12,35 \%$ & $-11,99 \%$ \\
\hline Maximum & $12,41 \%$ & $6,61 \%$ & $8,77 \%$ & $5,83 \%$ & $3,87 \%$ & $4,41 \%$ \\
\hline Sum & $79,46 \%$ & $63,82 \%$ & $27,71 \%$ & $22,43 \%$ & $0,89 \%$ & $28,51 \%$ \\
\hline Accoent & 891 & 891 & 891 & 891 & 891 & 891 \\
\hline Confidence level $(95,0 \%)$ & $0,11 \%$ & $0,10 \%$ & $0,10 \%$ & $0,10 \%$ & $0,09 \%$ & $0,08 \%$ \\
\hline & Colonial & $\begin{array}{c}\text { Inmobiliaria } \\
\text { del Sur }\end{array}$ & Realia & \multicolumn{2}{|c|}{$\begin{array}{c}\text { Renta } \\
\text { Corporación }\end{array}$} & Montebalito \\
\hline Mean & $0,06 \%$ & $0,10 \%$ & $0,03 \%$ & \multicolumn{2}{|c|}{$0,29 \%$} & $0,16 \%$ \\
\hline Typical error & $0,05 \%$ & $0,10 \%$ & $0,09 \%$ & \multicolumn{2}{|c|}{$0,20 \%$} & $0,11 \%$ \\
\hline Median & $0,00 \%$ & $0,00 \%$ & $0,00 \%$ & \multicolumn{2}{|c|}{$0,00 \%$} & $0,00 \%$ \\
\hline Mode & $0,00 \%$ & $0,00 \%$ & $0,00 \%$ & \multicolumn{2}{|c|}{$0,00 \%$} & $0,00 \%$ \\
\hline Standard deviation & $1,58 \%$ & $2,87 \%$ & $2,70 \%$ & \multicolumn{2}{|c|}{$5,83 \%$} & $3,18 \%$ \\
\hline Variance & $0,02 \%$ & $0,08 \%$ & $0,07 \%$ & \multicolumn{2}{|c|}{$0,34 \%$} & $0,10 \%$ \\
\hline Curtosis & 4,19 & 14,76 & 17,11 & & 3,05 & 17,92 \\
\hline Asymmetry coefficient & $-0,36$ & 1,59 & 0,06 & & ,79 & 2,51 \\
\hline Range & $18,25 \%$ & $42,45 \%$ & $44,91 \%$ & & $90 \%$ & $42,67 \%$ \\
\hline Minimum & $-11,05 \%$ & $-13,42 \%$ & $-25,18 \%$ & & $51 \%$ & $-14,93 \%$ \\
\hline Maximum & $7,20 \%$ & $29,03 \%$ & $19,73 \%$ & & $39 \%$ & $27,74 \%$ \\
\hline Sum & $52,62 \%$ & $86,92 \%$ & $25,59 \%$ & & $93 \%$ & $142,71 \%$ \\
\hline Accoent & 891 & 891 & 891 & & 91 & 891 \\
\hline Confidence level $(95,0 \%)$ & $0,10 \%$ & $0,19 \%$ & $0,18 \%$ & & $8 \%$ & $0,21 \%$ \\
\hline
\end{tabular}

Source: Authors from Bolsa de Madrid Data 